\title{
Uptake and trophic transfer of nitrogen and carbon in a temperate forested headwater stream
}

\author{
Meritxell Abril $^{1}$ - Elliot Bastias ${ }^{2} \cdot$ Daniel von Schiller ${ }^{3} \cdot$ Eugènia Martí $^{2} \cdot$ Margarita Menéndez $^{1} \cdot$ Isabel Muñoz $^{1}$
}

Received: 3 April 2019 / Accepted: 23 September 2019

(c) Springer Nature Switzerland AG 2019

\begin{abstract}
In temperate headwater streams, riparian forests hinder the development of algae by reducing light availability and generate large inputs of detritus. Microbial assemblages associated with this detritus are expected to strongly influence in-stream elemental cycling. However, most research has focused on quantifying nitrogen $(\mathrm{N})$ cycling while we know little about the coupling of $\mathrm{N}$ and carbon (C) cycling. We conducted a simultaneous whole-reach tracer addition of ${ }^{15} \mathrm{~N}$-ammonium and ${ }^{13} \mathrm{C}$-acetate in a forested headwater stream to examine the importance of different primary uptake compartments (e.g. epilithic biofilm, leaves, small wood) on $\mathrm{N}$ and $\mathrm{C}$ uptake, storage, and transfer to consumers. We predicted high whole-reach uptake of $\mathrm{N}$ and $\mathrm{C}$ from the water column to satisfy requirements of microbial decomposers. We also predicted a dominant role of the abundant detrital compartments, especially leaf litter, in the uptake, storage and trophic transfer of these labile forms of $\mathrm{N}$ and $\mathrm{C}$. Our results show efficient immobilization of both ammonium and acetate along the study reach. Leaf litter showed the highest percentage of contribution among all compartments to whole-reach ammonium and acetate uptake. We also found evidence of rapid transfer of $\mathrm{N}$ and $\mathrm{C}$ to higher trophic levels, thereby extending the retention time of these elements within the ecosystem. Overall, our study provides relevant insights into the influence of detritus on $\mathrm{N}$ and $\mathrm{C}$ cycling in headwater streams.
\end{abstract}

Keywords Primary uptake compartments $\cdot$ Leaf litter $\cdot$ Food web $\cdot$ Stable isotopes $\cdot$ Tracer addition $\cdot$ Nitrogen $\cdot$ Carbon

\section{Introduction}

Headwater streams are characterized by strong interactions with the surrounding terrestrial ecosystem, from which they receive large inputs of nutrients, such as nitrogen $(\mathrm{N})$, and organic carbon (C) (Lowe and Likens 2005). Biotic assemblages developed on streambed substrata play a relevant

Electronic supplementary material The online version of this article (https://doi.org/10.1007/s00027-019-0672-x) contains supplementary material, which is available to authorized users.

Isabel Muñoz

imunoz@ub.edu

1 Department of Evolutionary Biology, Ecology and Environmental Sciences, Universitat de Barcelona, Av. Diagonal 643, 08028 Barcelona, Spain

2 Integrative Freshwater Ecology Group, Centre d'Estudis Avançats de Blanes (CEAB-CSIC), 17300 Blanes, Spain

3 Department of Plant Biology and Ecology, Faculty of Science and Technology, University of the Basque Country, PO Box 644, 48080 Bilbao, Spain role in in-stream $\mathrm{N}$ and $\mathrm{C}$ cycling because they use these elements as resources to meet their energy and elemental demand (Peterson et al. 2001; Bernhardt and McDowell 2008). These assemblages, hereafter referred to as primary uptake compartments (PUCs; Tank et al. 2018), include primary producers, such as bryophytes, macrophytes or algae, which mostly obtain nutrients from the water column (Peipoch et al. 2014). PUCs also include heterotrophic organisms, mainly bacteria and fungi associated with detrital particulate organic matter (e.g., leaf litter, wood and fine organic particles), which can take up $\mathrm{N}$ and organic $\mathrm{C}$ from the water column, but also from the substrate where they develop (Gessner et al. 1999; Cheever et al. 2013; Pastor et al. 2014). All these PUCs are also important food resources for higher trophic levels, providing a direct pathway for the transfer of dissolved $\mathrm{N}$ and $\mathrm{C}$ in food webs, which can delay the export of these elements to downstream reaches (Hall and Meyer 1998; Dodds et al. 2000).

In forested headwater streams, the surrounding riparian vegetation hinders the development of primary producers by reducing light availability in the stream channel (von 
Schiller et al. 2007). Nevertheless, riparian vegetation supplies large inputs of detrital particulate organic matter, mostly in the form of leaf litter (Pozo et al. 1997), which promotes the development of heterotrophic organisms that dominate the overall stream metabolism (Vannote et al. 1980; Wallace et al. 1997). In this context, microbial assemblages associated with leaf litter may exert a strong influence on the uptake, storage and trophic transfer of $\mathrm{N}$ and dissolved organic $\mathrm{C}$ (DOC) in headwater streams, especially in autumn when a large input of detritus occurs. In fact, several studies have indicated that forested streams show higher rates of nutrient uptake during autumn, coinciding with the peak of heterotrophic activity (Mulholland et al. 1985; Webster et al. 2000; Mulholland 2004; Goodale et al. 2009). On the one hand, microbial assemblages growing on leaf litter generally have lower $\mathrm{C}$ to $\mathrm{N}$ ratios than detritus, and they compensate for this elemental imbalance by relying on $\mathrm{N}$ from the water column (Sanzone et al. 2001; Dodds et al. 2004; Pastor et al. 2014). In this line, Tank et al. (2000) reported high uptake of $\mathrm{NH}_{4}{ }^{+}$ by the microbial assemblages colonizing leaf litter during autumn, showing the relevance of this compartment for $\mathrm{N}$ cycling at whole-reach scale. On the other hand, leaf litter can be a key source of organic $\mathrm{C}$ for heterotrophs. In this regard, Hall and Meyer (1998) found that the large abundance of detritus in forested streams during autumn can reduce the uptake of DOC from the water column by bacteria, which is considered the main driver of biological DOC removal in streams (Bott et al. 1984). Nevertheless, some studies have indicated that microbial assemblages on leaf litter can also rely on stream water DOC (Baldy et al. 2007; Pastor et al. 2014), although this uptake pathway seems strongly influenced by the DOC quality and composition (Mineau et al. 2016). Understanding these mechanisms is key to evaluate implications for DOC cycling in streams at broader spatial scales.

Experimental tracer additions of isotopically labelled compounds are a powerful tool for tracking the uptake of $\mathrm{N}$ and $\mathrm{C}$ from the water column into PUCs and their further transfer to higher trophic levels, without altering the ambient concentration of these elements in the stream water (Newbold et al. 1983; Mulholland et al. 2000a; Glibert et al. 2018). In the case of $\mathrm{N}$, additions have generally used salts of inorganic $\mathrm{N}$ compounds, such as nitrate $\left(\mathrm{NO}_{3}{ }^{-}\right)$and ammonium $\left(\mathrm{NH}_{4}{ }^{+}\right)$, enriched with the ${ }^{15} \mathrm{~N}$ stable isotope as tracer (Peterson et al. 2001; Mulholland et al. 2004). Water column $\mathrm{NH}_{4}{ }^{+}$is the preferred form of $\mathrm{N}$ for assimilatory uptake by autotrophic and heterotrophic microbial assemblages (Tank et al. 2008), and it can also be transformed into $\mathrm{NO}_{3}{ }^{-}$by nitrifying bacteria (Peterson et al. 2001). In forested headwater streams, results from whole-reach ${ }^{15} \mathrm{~N}$ $\mathrm{NH}_{4}{ }^{+}$tracer additions show consistently high uptake efficiencies for $\mathrm{NH}_{4}^{+}$(Tank et al. 2018).
Unlike pathways of in-stream $\mathrm{N}$ uptake, pathways of DOC uptake in forested headwater streams have been examined to a lesser extent. Some studies have used additions of ${ }^{13} \mathrm{C}$-labelled organic compounds as proxies for DOC, to follow the heterotrophic pathway of DOC uptake and storage in streams. The most frequently used DOC sources were either acetate (Hall 1995; Hall et al. 1998; Simon et al. 2003), a monomeric organic molecule representative of the labile fraction of stream DOC, or leachates from tree tissue (Wilcox et al. 2005; Kaplan et al. 2008; Wiegner et al. 2015). These studies focused mainly on DOC uptake by heterotrophic bacteria and its transfer to higher trophic levels, and showed a strong link from stream water DOC to bacteria and macroinvertebrates in headwater streams (Meyer 1994; Hall 1995). Surprisingly, to the best of our knowledge, only one previous study (Collins et al. 2016) has simultaneously examined the coupling between stream water $\mathrm{N}$ and DOC uptake using simultaneous stable isotope tracer additions of the two elements. Collins et al. (2016) focused on the trophic link between bacteria and consumers and the influence of light availability on this link; however, their study did not examine and compare the relative contribution of different PUCs to the uptake of N and DOC at the wholereach scale. Nevertheless, due to the strong linkage between mechanisms involved in $\mathrm{N}$ and $\mathrm{C}$ cycling in streams (Bernhardt and Likens 2002; Trimmer et al. 2012; Ghosh and Leff 2013) and the observed influence of the C:N ratio on N uptake, important insights can arise from the evaluation of how PUCs simultaneously contribute to $\mathrm{N}$ and $\mathrm{C}$ dynamics in streams. Different proportions of PUCs could determine different retention and removal rates of these elements at reach-scale and influence their downstream export as well as mineralization and release to the atmosphere.

The aim of this study was to examine the relative contribution of microbial assemblages developed on the different PUCs to in-stream $\mathrm{N}$ and DOC cycling. We performed a simultaneous whole-reach tracer addition of ${ }^{15} \mathrm{~N}^{-\mathrm{NH}_{4}}{ }^{+}$and ${ }^{13} \mathrm{C}$-acetate-both labile forms of $\mathrm{N}$ and $\mathrm{C}$ - in a headwater stream, and we evaluated the relative role of the different PUCs on $\mathrm{N}$ and $\mathrm{C}$ uptake, storage, and transfer to consumers. We predicted high whole-reach uptake of $\mathrm{N}$ and $\mathrm{C}$ from the water column to satisfy requirements of microbial decomposers in this headwater stream. Among PUCs, we expected a dominant role of detrital PUCs, especially leaf litter, in the uptake, and storage of these labile forms of $\mathrm{N}$ and $\mathrm{C}$. Finally, we predicted that transfer of $\mathrm{N}$ and $\mathrm{C}$ from PUCs to higher trophic levels would vary among consumers depending on their feeding strategy and the uptake patterns of these elements among PUCs. 


\section{Methods}

\section{Study site}

The Riera de Castellar is a calcareous second-order stream within the Fluvià River watershed (NE Iberian Peninsula). The climate in this area is Mediterranean, characterized by dry, warm summers and scarce precipitation occurring primarily in the spring and autumn. This stream is characterized by an intermittent flow regime and surface water flow usually ceases during summer. We selected a $77-\mathrm{m}$ reach $\left(42^{\circ} 14^{\prime} 57.043^{\prime \prime} \mathrm{N}\right.$ and $\left.2^{\circ} 29^{\prime} 21.738^{\prime \prime} \mathrm{E}\right)$ located at $415 \mathrm{~m}$ above sea level and without observed lateral outflows and inflows. Land cover in the watershed upstream of the selected reach $\left(1.55 \mathrm{~km}^{2}\right)$ consists primarily of mixed forest (96\%), with some agricultural (3\%) and urban $(0.1 \%)$ areas (Land Cover Map of Catalonia 2009, CREAF). The selected reach was characterized by alternating riffles and pools $(73 \%$ and $27 \%$ of the total reach length, respectively). Streambed substrata were a mixture of sand (28\%), gravel (28\%), cobbles (21\%) and bedrock (23\%). The reach was flanked by a dense riparian forest dominated by Quercus ilex, Corylus avellana, Salix spp. and Populus nigra.

\section{Whole-reach addition of ${ }^{15} \mathrm{~N}$ and ${ }^{13} \mathrm{C}$ tracers}

One week prior to the whole-reach tracer addition, a shortterm constant rate addition of a solution including a conservative tracer (i.e., $\mathrm{Cl}^{-}$, as $\mathrm{NaCl}$ ) and a regular salt of $\mathrm{NH}_{4}{ }^{+}$(i.e., $\mathrm{NH}_{4} \mathrm{Cl}$ ) was conducted in the selected reach to estimate the appropriate reach length, establish sampling stations, determine stream discharge and detect possible groundwater and lateral inflows and outflows. The selected site for the tracer addition was in a turbulent zone to allow fast mixing of the added solution with stream water. The first sampling station was established where this mixing was complete, based on cross-section measurements of stream conductivity. We established six sampling stations, which were situated at $17,27,37,47,57$ and $77 \mathrm{~m} \mathrm{(1st} \mathrm{to}$ 6th station) downstream of the addition site. An additional sampling station was established $10 \mathrm{~m}$ upstream from the addition site (Up station) and served as a reference site of ambient stable isotope conditions.

The whole-reach ${ }^{15} \mathrm{~N}^{-\mathrm{NH}_{4}}{ }^{+}$and ${ }^{13} \mathrm{C}$-acetate addition was conducted from 9 to 16 December 2013, just after autumn rainfalls and peak leaf fall, to ensure stable hydrological conditions and a well-developed microbial assemblage on leaf litter. The tracer addition was performed following procedures adapted from Hall and Meyer (1998), Mulholland et al. (2000b) and Tank et al. (2000).
At the addition site, we simultaneously added $267 \mathrm{mg}$ of ${ }^{15} \mathrm{~N}-\mathrm{NH}_{4} \mathrm{Cl}\left({ }^{15} \mathrm{~N}-\mathrm{NH}_{4}{ }^{+} ; 72.7 \mathrm{mg}{ }^{15} \mathrm{~N} ; 99 \%\right.$ enriched $)$ and $16.5 \mathrm{~g}$ of ${ }^{13} \mathrm{C}$-1-sodium acetate $\left({ }^{13} \mathrm{C}\right.$-acetate; $4.8 \mathrm{~g}{ }^{13} \mathrm{C}$; 99\% enriched) to the stream. The solute addition, containing filtered stream water ( $300 \mu \mathrm{m}$ mesh-size sieve) and the stable isotope tracers, was released from a 110-L carboy at a constant rate $\left(10 \mathrm{~mL} \mathrm{~min}^{-1}\right)$ using a battery-powered peristaltic pump. Solute injection rate and battery status were checked daily during the addition period.

We collected water samples for nutrient chemistry and isotopic ${ }^{15} \mathrm{~N}$ and ${ }^{13} \mathrm{C}$ signals at each sampling station just before the tracer addition (i.e., background sampling), $24 \mathrm{~h}$ and 7 days after the beginning of the tracer addition (i.e., plateau $24 \mathrm{~h}$ and plateau 7 days, respectively), and $4 \mathrm{~h}$ and 7 days after the end of the addition (i.e., post $24 \mathrm{~h}$ and post 7 days, respectively). All water samples were immediately filtered through pre-ashed glass fiber filters (Whatman GF/F, Whatman International, Maidstone, UK). Filtered samples for determination of nutrient chemistry $(15 \mathrm{~mL}$, two replicates per station) and ${ }^{15} \mathrm{~N}-\mathrm{NO}_{3}(1 \mathrm{~L}$, one replicate per station) were stored on ice in the field and then at $-20^{\circ} \mathrm{C}$ in the laboratory until analysis. Samples for DOC concentration (30 mL, one replicate per station) and ${ }^{13} \mathrm{C}-\mathrm{DOC}(30 \mathrm{~mL}$, one replicate per station) were acidified with 6 drops of $10 \%$ $\mathrm{HCl}$ and stored at $4{ }^{\circ} \mathrm{C}$ until analysis. Samples for ${ }^{15} \mathrm{~N}-\mathrm{NH}_{4}$ (3 $\mathrm{L}$, one replicate per station) were immediately processed as described in the laboratory methods section.

During the addition, stream water level was monitored every $10 \mathrm{~min}$ at the 6th station using a pressure transducer (Solinst Levelogger Junior Model 3001 and Solinst Barologger Gold Model 3001, Solinst Ltd, Georgetown, Canada). Short-term constant rate additions of $\mathrm{Cl}^{-}$(as $\mathrm{NaCl}$ ) were also conducted each time water samples were collected to determine stream discharge and to estimate tracer dilution at each station (Gordon et al. 1992). With these data, we developed an empirical relationship between stream water level and discharge that was used to estimate continuous values of stream discharge over the course of the addition. Water temperature, conductivity, dissolved oxygen concentration (DO) and \% saturation were recorded continuously at the Up station and the 6th station with optical oxygen probes (YSI 6150 connected to YSI 600 OMS; YSI Corporation, Yellow Springs, OH, USA).

\section{Sampling of PUCs and macroinvertebrates}

One day after the end of the addition, we determined wetted width, channel depth, percent coverage of the different substrate types (bedrocks, gravel, sand and cobbles), and the coverage of PUCs and stream habitats (riffle or pool) using cross-sectional point transects located every $5 \mathrm{~m}$ along the selected reach. Sampled PUCs consisted of epilithic biofilm (hereafter 'epilithon'), submerged bryophytes, fine 
benthic organic matter $(\mathrm{FBOM},<1 \mathrm{~mm})$ and coarse benthic organic matter $(\mathrm{CBOM},>1 \mathrm{~mm})$ sorted into leaf litter and small wood. Reach-weighted standing stocks of biomass, expressed as ash free dry mass ( $\mathrm{g}$ AFDM m ${ }^{-2}$ reach), and $\mathrm{N}$ and $\mathrm{C}\left(\mathrm{g} \mathrm{N} \mathrm{m}^{-2}\right.$ reach and $\mathrm{g} \mathrm{C} \mathrm{m}^{-2}$ reach, respectively) for each PUC were estimated using the percent reach coverage and the average patch-specific estimates of AFDM and $\mathrm{N}$ and $\mathrm{C}$ content (as \% dry mass) along the reach. Samples to measure the patch-specific biomass for epilithon were obtained by scraping the surface of three randomly collected cobbles at each station and filtering the slurries onto pre-ashed glass fiber filters. The cobble surface was estimated by covering it with aluminium foil and applying a weight to area relation. Samples for CBOM biomass were collected from three corers $\left(400 \mathrm{~cm}^{2}\right)$ placed into the sediment at each station. CBOM samples were sorted into small wood and leaves. Bryophytes, when present at the sampling stations, were sampled by scraping the material found within a $225 \mathrm{~cm}^{2}$ corer. Samples for FBOM were collected using a $346 \mathrm{~cm}^{2}$ corer placed over the sediment surface at each sampling station. The water depth in the cylinder was measured, and after sediments were vigorously agitated, aliquots $(\sim 40 \mathrm{~mL})$ of the total volume were filtered onto pre-ashed glass fiber filters. Additionally, concentration of suspended particulate organic matter (SPOM) in stream water was determined by filtering a known volume of water from each station onto pre-ashed glass fiber filters. For all PUCs and SPOM, we collected 3-5 samples per sampling station and combined them to make one composite sample for analysis of elemental content and ${ }^{15} \mathrm{~N}$ and ${ }^{13} \mathrm{C}$ isotopes. These samples were collected at plateau 7 days, and at $24 \mathrm{~h}, 7$ days, and 14 days after the end of the addition (post $24 \mathrm{~h}, 7$ days and 14 days) following the same methods as with the standingstock sampling. Samples from the Up station were used as the ambient values for ${ }^{15} \mathrm{~N}$ and ${ }^{13} \mathrm{C}$ isotopic signal for each PUC on each sampling date. All samples were dried at $60{ }^{\circ} \mathrm{C}$ until reaching a constant weight and further processed as described in the laboratory methods section.

Macroinvertebrates were collected at plateau $7 \mathrm{~d}$. For biomass estimations, organisms were sampled in riffles using a Surber net (three replicates, $0.06 \mathrm{~m}^{2}, 250 \mu \mathrm{m}$ mesh) at each sampling station. Samples were preserved in a $70 \%$ alcohol solution, and all individuals were sorted from the debris upon arrival to the laboratory. All taxa were identified and counted. The invertebrate biomass was estimated by a length/dry mass conversion, based on the application of a regression function for each specific taxon (Meyer 1989; Burgherr and Meyer 1997). Abundances and biomass were converted to units of streambed surface $\left(\mathrm{m}^{2}\right)$ based on the percentage of riffle habitat in the reach. The most abundant macroinvertebrate species (Table S1) that were present at all stations, including the Up station, were selected for the elemental and ${ }^{15} \mathrm{~N}$ and ${ }^{13} \mathrm{C}$ analyses. These invertebrates were hand-picked directly in the field at the sampling stations and stored in plastic vials with a small amount of stream water, where they were kept for $24 \mathrm{~h}$ to allow them to clear their gut contents. After this period, we removed the snails from their shells, and all individuals were dried at $60{ }^{\circ} \mathrm{C}$ until constant weight and stored in a desiccator until further processing. Organisms from shredders and collector-filterer feeding groups could not be used for isotopic analyses because in the former, density and size were too small for reliable isotopic analyses, and in the latter, there were no collector-filterers at the Up station, so we were unable to calculate isotopic enrichment.

\section{Laboratory methods}

Water samples were analysed for $\mathrm{NH}_{4}{ }^{+}, \mathrm{NO}_{3}{ }^{-}$, and soluble reactive phosphorus (SRP) following standard colorimetric methods (American Public Health Association 1995) on an Automatic Continuous Flow Futura-Alliance Analyser (Alliance Instruments, France). The concentration of acetate was analysed by ion exclusion chromatography with an HPX-87H organic acid column $(300 \times 7.8 \mathrm{~mm}$; Aminex, Bio-Rad, UK) and a mobile phase of $0.01 \mathrm{M} \mathrm{H}_{2} \mathrm{SO}_{4}$ at a flow rate of $0.8 \mathrm{~mL} \mathrm{~min}{ }^{-1}$ at $65{ }^{\circ} \mathrm{C}$. The isotopic signals of ${ }^{15} \mathrm{~N}-\mathrm{NH}_{4}{ }^{+}$and ${ }^{15} \mathrm{~N}_{-} \mathrm{NO}_{3}{ }^{-}$were determined following the ammonia-diffusing technique adapted from Holmes et al. (1998) and Sigman et al. (1997), respectively. For the ${ }^{15} \mathrm{~N}$ $\mathrm{NO}_{3}{ }^{-}$analyses, we amended each water sample with $3 \mathrm{~g}$ of $\mathrm{MgO}$ and $5 \mathrm{~g}$ of $\mathrm{NaCl}$, and then, we boiled it to concentrate the water volume and remove the dissolved $\mathrm{NH}_{4}{ }^{+}$. Water samples were then amended with $0.5 \mathrm{mg} \mathrm{MgO}$ and $0.5 \mathrm{mg}$ Devarda's alloy (to reduce $\mathrm{NO}_{3}{ }^{-}$to $\mathrm{NH}_{4}{ }^{+}$) and then processed as described for ${ }^{15} \mathrm{~N}-\mathrm{NH}_{4}{ }^{+}$estimates. The ${ }^{15} \mathrm{~N}_{-} \mathrm{NH}_{4}{ }^{+}$ samples were amended with $3 \mathrm{~g} \mathrm{~L}^{-1}$ of $\mathrm{MgO}, 50 \mathrm{~g} \mathrm{~L}^{-1}$ of $\mathrm{NaCl}$ and a Teflon filter pack containing a pre-ashed Whatman GF/D glass fiber filter $(1 \mathrm{~cm} \varnothing)$ acidified with $25 \mathrm{~mL}$ of $2.5 \mathrm{M} \mathrm{KHSO}_{4}$ and incubated on a shaker at $40{ }^{\circ} \mathrm{C}$ for 4 weeks. Due to the low $\mathrm{NH}_{4}{ }^{+}$concentration in the stream water, the ${ }^{15} \mathrm{~N}^{-\mathrm{NH}_{4}}{ }^{+}$samples were spiked with $20 \mu \mathrm{g}$ of unlabelled $\mathrm{NH}_{4}{ }^{+}$to reach the detection limit needed for the $\mathrm{N}$ mass spectrometer analyses. To determine the influence of the $\mathrm{NH}_{4}{ }^{+}$spike on the ${ }^{15} \mathrm{~N}$ signal, we added $20 \mu \mathrm{g}$ of unlabelled $\mathrm{NH}_{4}^{+}$to $3 \mathrm{~L}$ deionized water and processed these samples identically to the ${ }^{15} \mathrm{~N}-\mathrm{NH}_{4}{ }^{+}$water samples. At the end of the incubation, we removed the filter packs, dried them in desiccators for 4 days, encapsulated the filters in tins and stored them until the ${ }^{15} \mathrm{~N}$ analysis (see below). The DOC concentration was determined on a Shimadzu TOC-V CSH analyser (Shimadzu Corporation, Kyoto, Japan). Water samples of the ${ }^{13} \mathrm{C}$-DOC were bubbled for 6 min with compressed nitrogen gas $\left(\mathrm{N}_{2}\right)$ prior to the isotopic analyses to remove gaseous inorganic $\mathrm{C}$ retained after acidification. After that, the samples were analysed by FIA-IRMS (Flow 
Injection Analysis-Isotope Ratio Mass Spectrometry) using a system composed of an LC unit (Surveyor MS-pump with autosampler) coupled to a DeltaV-Advantage IRMS via an LC-IsoLink interface (Thermo Fisher Scientific, Germany) to determine their ${ }^{13} \mathrm{C}:{ }^{12} \mathrm{C}$ ratio.

Samples from all PUCs were dried at $60{ }^{\circ} \mathrm{C}$ for several days and weighed to the nearest $0.1 \mathrm{mg}$ to determine the dry mass. A subsample of the dried material was combusted at $500{ }^{\circ} \mathrm{C}$ for $4 \mathrm{~h}$ to calculate the ash-free dry mass (AFDM) for biomass standing-stock estimations. For the elemental and isotopic analyses of $\mathrm{N}$ and $\mathrm{C}$, another subsample of the dried material of bryophytes, leaf litter and small wood was ground to a fine powder, weighed to the nearest $0.001 \mathrm{mg}$, encapsulated in tins and stored until analysis. For the epilithon, FBOM and SPOM samples, discs of a known surface area were cut out from the previously oven-dried filters, weighed to the nearest $0.001 \mathrm{mg}$, encapsulated in tins and processed as the rest of samples. For macroinvertebrates, the dried organisms were ground, weighed to the nearest $0.001 \mathrm{mg}$, encapsulated in tins and stored until analysis. While the largest macroinvertebrates were analysed individually, for taxa of smaller size we used a composite sample of 2-5 individuals for each station. Whole-body samples were analysed for all taxa except for odonates, from which we used only muscle tissue.

Encapsulated samples of ${ }^{15} \mathrm{~N}_{-} \mathrm{NO}_{3}{ }^{-},{ }^{15} \mathrm{~N}-\mathrm{NH}_{4}{ }^{+}, \mathrm{SPOM}$, PUCs and macroinvertebrates were analysed for $\mathrm{N}$ and $\mathrm{C}$ content (as a percentage of the total dry mass) and the ${ }^{15} \mathrm{~N}$ and ${ }^{13} \mathrm{C}$ isotopic signal by the EA-IRMS technique (Elemental Analysis-Isotope Ratio Mass Spectrometry) using a Carlo-Erba Flash 1112 series elemental analyser (CarloErba, Italy) interfaced with a Finnigan Delta $\mathrm{C}$ isotope ratio mass spectrometer (IRMS) via a Finnigan Conflo III interface (Thermo Fisher Scientific, Germany). Measurement precision was $0.1 \%$ and $0.3 \%$ for ${ }^{13} \mathrm{C}:{ }^{12} \mathrm{C}$ and ${ }^{15} \mathrm{~N}:{ }^{14} \mathrm{~N}$, respectively.

\section{Parameter calculation}

Data for ${ }^{13} \mathrm{C}$ and ${ }^{15} \mathrm{~N}$ were expressed as $\delta$ values in per mil units (\%o) using international reference standards Vienna Pee Dee Belemnite and air, respectively. The $\delta^{13} \mathrm{C}$ and $\delta^{15} \mathrm{~N}$ values from the isotope tracer addition were corrected for ambient isotope values measured at the Up station to estimate the isotopic enrichment during the addition.

We estimated the uptake length $\left(S_{w}\right.$, m; i.e., the average distance travelled by a molecule before being removed from the water column) and the uptake velocity $\left(V_{f}, \mathrm{~mm} \mathrm{~min}^{-1}\right.$; i.e., the velocity at which a nutrient molecule is removed from the water column) for $\mathrm{NH}_{4}{ }^{+}$and acetate at plateau $24 \mathrm{~h}$ and 7 days based on Mulholland et al. (2000b). The $S_{w}$ was calculated as the inverse of the slope of the linear regression between the natural logarithm of the tracer ${ }^{15} \mathrm{~N}_{-} \mathrm{NH}_{4}{ }^{+}$ or ${ }^{13} \mathrm{C}$-DOC flux in the water column at each sampling station and the distance downstream. The $V_{f}$ was calculated by dividing specific discharge (i.e., discharge/wetted width) by the $S_{w}$ of ${ }^{15} \mathrm{~N}_{-} \mathrm{NH}_{4}{ }^{+}$and ${ }^{13} \mathrm{C}$-acetate. Tracer ${ }^{15} \mathrm{~N}^{-\mathrm{NH}_{4}}{ }^{+}$or ${ }^{13} \mathrm{C}$-DOC fluxes $\left(\mu \mathrm{g}{ }^{15} \mathrm{~N} \mathrm{~s}^{-1}\right.$; $\left.\mathrm{mg}{ }^{13} \mathrm{C} \mathrm{s}^{-1}\right)$ were estimated using ambient-corrected $\delta^{15} \mathrm{~N}-\mathrm{NH}_{4}{ }^{+}$or $\delta^{13} \mathrm{C}$-DOC, the $\mathrm{NH}_{4}{ }^{+}$ or DOC concentrations, and dilution-corrected values of stream discharge at each sampling station. We estimated whole-reach ${ }^{15} \mathrm{~N}-\mathrm{NH}_{4}{ }^{+}$areal uptake from the water column $\left(U_{\mathrm{NH} 4 \text { water }} ; \mathrm{mg} \mathrm{N} \mathrm{m}^{-2} \mathrm{day}^{-1}\right.$ ) by multiplying $V_{f}$ by the mean $\mathrm{NH}_{4}{ }^{+}$concentration. We calculated the whole-reach areal nitrification $\left(U_{\mathrm{NIT}} ; \mathrm{mg} \mathrm{N} \mathrm{m}^{-2} \mathrm{day}^{-1}\right)$ using the backgroundcorrected $\delta^{15} \mathrm{~N}_{-} \mathrm{NO}_{3}{ }^{-}$at plateau $24 \mathrm{~h}$ following procedures by Mulholland et al. (2000b) and Hamilton et al. (2001). Even though we used ${ }^{13} \mathrm{C}$-acetate as a tracer, we estimated $\delta^{13} \mathrm{C}$-DOC in water because the acetate concentration was below the detection limit $\left(0.5 \mathrm{mg} \mathrm{L}^{-1}\right)$. We estimated $S_{w}$ and $V_{f}$ for acetate from longitudinal changes in $\delta^{13} \mathrm{C}$-DOC; however, we were not able to calculate areal uptake for the whole reach because we would need to assume that all stream water DOC was acting as a labile fraction of $\mathrm{C}$ (i.e., acetate); and thus, this would probably overestimate areal uptake of DOC.

The reach-weighted masses of isotopic enrichment (in $m g{ }^{15} \mathrm{~N} \mathrm{~m}^{-2}$ reach and $\mathrm{mg}^{13} \mathrm{C} \mathrm{m}^{-2}$ reach) measured for each PUC and macroinvertebrate taxon were calculated as the product of the fraction of ${ }^{15} \mathrm{~N}$ or ${ }^{13} \mathrm{C}$, obtained using the ambient-corrected $\delta^{15} \mathrm{~N}$ and $\delta^{13} \mathrm{C}$, and the estimated standing stock of $\mathrm{N}$ and $\mathrm{C}$ at the reach scale $\left(\mathrm{mg} \mathrm{N} \mathrm{m}^{-2}\right.$ reach; $\mathrm{mg} \mathrm{C}$ $\mathrm{m}^{-2}$ reach). Using samples from plateau $7 \mathrm{~d}$, compartmentspecific areal uptake for $\mathrm{NH}_{4}^{+}\left(U_{\mathrm{NH} 4} ; \mathrm{mg} \mathrm{N} \mathrm{m}^{-2} \mathrm{~d}^{-1}\right)$ and acetate $\left(U_{\text {acetate; }}, \mathrm{mg} \mathrm{C} \mathrm{m}^{-2} \mathrm{~d}^{-1}\right)$ were calculated as the reachweighted mass of tracer ${ }^{15} \mathrm{~N}$ or ${ }^{13} \mathrm{C}$ in each compartment divided by the time of addition (7 days) and the fraction of ${ }^{15} \mathrm{~N}$ or ${ }^{13} \mathrm{C}$ present in the water column at the same station and sampling time (Hamilton et al. 2001). These calculations were performed only with samples from the upper three stations (1st to 3rd station), since they were the least affected by the isotopic signal from $\mathrm{N}$ and $\mathrm{C}$ regeneration, and average values for these three stations were used as the compartment-specific areal uptake of ${ }^{15} \mathrm{~N}_{-} \mathrm{NH}_{4}{ }^{+}$and ${ }^{13} \mathrm{C}$-acetate at the reach scale. The turnover rates of $\mathrm{N}$ and $\mathrm{C}\left(\mathrm{d}^{-1}\right)$ for each benthic biomass compartment were estimated from the decay in the ${ }^{15} \mathrm{~N}$ and ${ }^{13} \mathrm{C}$ signal at the 1 st station over the first 14 days after the end of the addition (Mulholland et al. 2000b; Tank et al. 2000). We assumed first-order dynamics [i.e., slope of the linear relationship between $\ln \left({ }^{15}\right.$ Nbiomass $)$ or $\ln \left({ }^{13}\right.$ Cbiomass $)$ and time $]$. This approach assumes no reuptake of ${ }^{15} \mathrm{~N}$ released to water upstream, a reasonable assumption for the upper sampling station, but may result in slight underestimates of turnover rate. Turnover times were calculated as the inverse of turnover rates.

We also used ${ }^{15} \mathrm{~N}$ and ${ }^{13} \mathrm{C}$ labelling to estimate reach-scale $\mathrm{N}$ and $\mathrm{C}$ storage in PUCs and selected macroinvertebrate 
taxa at the end of the addition, expressed as a percentage of total ${ }^{15} \mathrm{~N}$ and ${ }^{13} \mathrm{C}$ added that was retained along the reach. For each compartment, we used the integration of the downstream decline in their tracer ${ }^{15} \mathrm{~N}$ or ${ }^{13} \mathrm{C}$ mass along the reach, considering a reach length of five times $S_{w}$ for each tracer (Mulholland et al. 2000a, b). In cases where the slope of the regression of tracer ${ }^{15} \mathrm{~N}$ or ${ }^{13} \mathrm{C}$ mass vs. distance was not significant $(\mathrm{p}>0.05)$, we used the mean $\operatorname{tracer}{ }^{15} \mathrm{~N}$ or ${ }^{13} \mathrm{C}$ mass for the entire reach (Hamilton et al. 2001; Ashkenas et al. 2004). The total mass export of ${ }^{15} \mathrm{~N}\left(\mathrm{mg}{ }^{15} \mathrm{~N}\right)$ and ${ }^{13} \mathrm{C}$ $\left(\mathrm{mg}{ }^{13} \mathrm{C}\right)$ tracers from the study reach as $\mathrm{NH}_{4}{ }^{+}, \mathrm{NO}_{3}{ }^{-}$, DOC and SPOM during the tracer addition was calculated from the product of the fluxes of tracer ${ }^{15} \mathrm{~N}\left(\mathrm{mg}{ }^{15} \mathrm{~N} \mathrm{~s}^{-1}\right)$ or ${ }^{13} \mathrm{C}$ $\left(\mathrm{mg}{ }^{13} \mathrm{C} \mathrm{s}^{-1}\right.$ ) at the 6th station at plateau 7 days for each form, the discharge, and the total addition time (Tank et al. 2018).

\section{Data analysis}

The profiles of ${ }^{15} \mathrm{~N}-\mathrm{NH}_{4}{ }^{+}$and ${ }^{13} \mathrm{C}$-DOC fluxes along the reach were compared between tracers and sampling times (plateau $24 \mathrm{~h}$ and plateau 7 days) by one-way analyses of covariance (ANCOVA) using distance as a co-variable for all tests.

To evaluate the feeding relation between macroinvertebrates and PUCs as potential benthic food resources, we calculated the ratio of $\delta^{15} \mathrm{~N}$ or $\delta^{13} \mathrm{C}$ signals between macroinvertebrates and their potential food resources (i.e., PUCs; Mulholland et al. 2000a; Simon et al. 2003). To determine these pairs, we used the most common food resources and feeding strategies described in the species traits list of Tachet et al. (2000). We used tracer ambient-corrected $\delta^{15} \mathrm{~N}$ or $\delta^{13} \mathrm{C}$ to remove the effect of trophic fractionation. Ratios were calculated for each sampling station only when both the macroinvertebrate and the food resource were labelled. Ratios for each station were averaged to obtain a representative consumer-food resource ratio at the reach scale. We also performed simple linear regressions between each consumer-food pair to illustrate these relations.

All statistical analyses were conducted using $\mathrm{R}$ version 3.2.2, with a significance level set at a $p<0.05$.

\section{Results}

\section{Environmental conditions}

Environmental conditions in the reach remained relatively constant over the course of the 7-day tracer addition. The stream was shallow (mean depth $\pm \mathrm{SE}=6 \pm 1 \mathrm{~cm}$ ) and relatively narrow (mean width $\pm \mathrm{SE}=1.9 \pm 0.2 \mathrm{~m}$, range $=0.9-2.9 \mathrm{~m}$ ), and discharge was low ranging between 3.0 and $3.8 \mathrm{~L} \mathrm{~s}^{-1}$ (mean $\pm \mathrm{SE}=3.33 \pm 0.01 \mathrm{~L}$ $\left.\mathrm{s}^{-1}\right)$. The water temperature was low, ranging from $2.3{ }^{\circ} \mathrm{C}$ to $4.4{ }^{\circ} \mathrm{C}$ (mean $\pm \mathrm{SE}=3.3 \pm 0.01{ }^{\circ} \mathrm{C}$ ). The stream water was highly oxygenated (mean $\pm \mathrm{SE}=13.0 \pm 0.01 \mathrm{mg}$ $\mathrm{O}_{2} \mathrm{~L}^{-1}$, range $=13.5-12.6 \mathrm{mg} \mathrm{O}_{2} \mathrm{~L}^{-1}$ ), and DO saturation approached $100 \%$ (mean $\pm \mathrm{SE}=97.6 \pm 0.03 \%$, range $=95.7-100.0 \%$ ). Conductivity was relatively high $\left(\right.$ mean $\pm \mathrm{SE}=513 \pm 0.1 \mu \mathrm{S} \mathrm{cm}^{-1}$, range $\left.=518-508 \mu \mathrm{S} \mathrm{cm}^{-1}\right)$, which is common in calcareous streams. In general, the concentration of dissolved inorganic nutrients was low, especially in the case of SRP (mean $\pm \mathrm{SE}=5 \pm 0.2 \mu \mathrm{g} \mathrm{P} \mathrm{L}^{-1}$ ) and $\mathrm{NH}_{4}{ }^{+}$(mean $\pm \mathrm{SE}=1 \pm 0.1 \mu \mathrm{g} \mathrm{N} \mathrm{L}^{-1}$ ). The concentration of $\mathrm{NO}_{3}{ }^{-}$averaged $102 \pm 4 \mu \mathrm{g} \mathrm{N} \mathrm{L}^{-1}$. The concentration of DOC was also low, averaging $1.30 \pm 0.03 \mathrm{mg} \mathrm{C} \mathrm{L}^{-1}$, and the concentration of acetate was below the analytical detection limit of $0.5 \mathrm{mg} \mathrm{L}^{-1}$. The tracer addition resulted in an increase of $5 \%$ and $0.2 \%$ of the ambient $\mathrm{NH}_{4}{ }^{+}$and DOC stream concentrations, respectively.

\section{Whole-reach ${ }^{15} \mathrm{~N}-\mathrm{NH}_{4}{ }^{+}$and ${ }^{13} \mathrm{C}$-acetate uptake}

Fluxes of tracer ${ }^{15} \mathrm{~N}-\mathrm{NH}_{4}{ }^{+}$and ${ }^{13} \mathrm{C}$-DOC at plateau decreased along the reach, and the decrease was similar between samplings done at plateau $24 \mathrm{~h}$ and at plateau 7 days (Sampling time $\times$ Distance: $F_{1,8}=1.2, p=0.3$ for ${ }^{15} \mathrm{~N}$ $\mathrm{NH}_{4}{ }^{+}$; and Sampling time $\times$Distance: $F_{1,8}=1.8, p=0.20$ for ${ }^{13} \mathrm{C}$-DOC). In addition, the fluxes of the two tracers showed a similar decrease along the reach (Tracer type $\times$ Distance, $F_{1,8}=0.5, p=0.50$; Fig. 1). The $S_{w}$ was $35 \mathrm{~m}$ for ${ }^{15} \mathrm{~N}^{-N_{4}}{ }_{4}^{+}$ and $44 \mathrm{~m}$ for ${ }^{13} \mathrm{C}$-acetate, and the $V_{f}$ was $3.0 \mathrm{~mm} \mathrm{~min}^{-1}$ for ${ }^{15} \mathrm{~N}_{-\mathrm{NH}_{4}}{ }^{+}$and $2.4 \mathrm{~mm} \mathrm{~min}{ }^{-1}$ for ${ }^{13} \mathrm{C}$-acetate. The total $U_{\mathrm{NH} 4 \text { water }}$ was $4.2 \mathrm{mg} \mathrm{N} \mathrm{m}^{-2}$ day $^{-1}$, and nitrification only accounted for $9 \%$ of this uptake. At post $24 \mathrm{~h}$ and post $7 \mathrm{~d}$

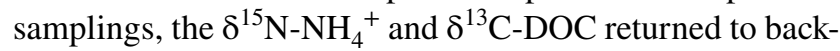
ground levels, and tracer fluxes of ${ }^{15} \mathrm{~N}^{-\mathrm{NH}_{4}}{ }^{+}$and ${ }^{13} \mathrm{C}$-DOC were practically undetectable.

\section{Contribution of PUCs to whole-reach ${ }^{15} \mathrm{~N}-\mathrm{NH}_{4}{ }^{+}$ and ${ }^{13} \mathrm{C}$-acetate uptake}

The total biomass standing stock of the sampled PUCs in the study reach was $125.1 \mathrm{~g} \mathrm{AFDM} \mathrm{m}^{-2}$. Detrital compartments (leaf litter, small wood and FBOM) accounted for 96\% of this stock, with leaf litter being the dominant compartment in the reach (49\% of total biomass standing stock). Epilithon and bryophytes only accounted for $4 \%$ in the total biomass standing stock. The $\mathrm{N}$ and $\mathrm{C}$ standing stocks accounted for the sampled PUCs in the reach were $1.62 \mathrm{~g} \mathrm{~N} \mathrm{~m}^{-2}$ and $74.8 \mathrm{~g} \mathrm{C} \mathrm{m}^{-2}$, respectively (Table 1). Detrital compartments accounted for $93 \%$ and $95 \%$ of the total standing stocks of $\mathrm{N}$ and $\mathrm{C}$, respectively, with leaf litter being the dominant compartment (55\% for N; $46 \%$ for C). Epilithon ( $6 \%$ for N; $4 \%$ for C) and bryophytes ( $1 \%$ for $\mathrm{N} ; 1 \%$ for $\mathrm{C}$ ) accounted for a small proportion of the total standing stocks of $\mathrm{N}$ and 
Fig. 1 Linear regressions for the natural logarithm of tracer ${ }^{15} \mathrm{~N}$ $\mathrm{NH}_{4}{ }^{+}$flux (continuous line) and tracer ${ }^{13} \mathrm{C}$-DOC flux (dashed line) in the water column over reach distance at plateau 7 days. The inverse of each regression slope is the uptake length $\left(S_{w}\right)$ of each tracer. The result from a one-way ANCOVA with tracer type $\left({ }^{15} \mathrm{~N}-\mathrm{NH}_{4}{ }^{+}\right.$or ${ }^{13} \mathrm{C}$-DOC) as factor and distance as a covariable is shown

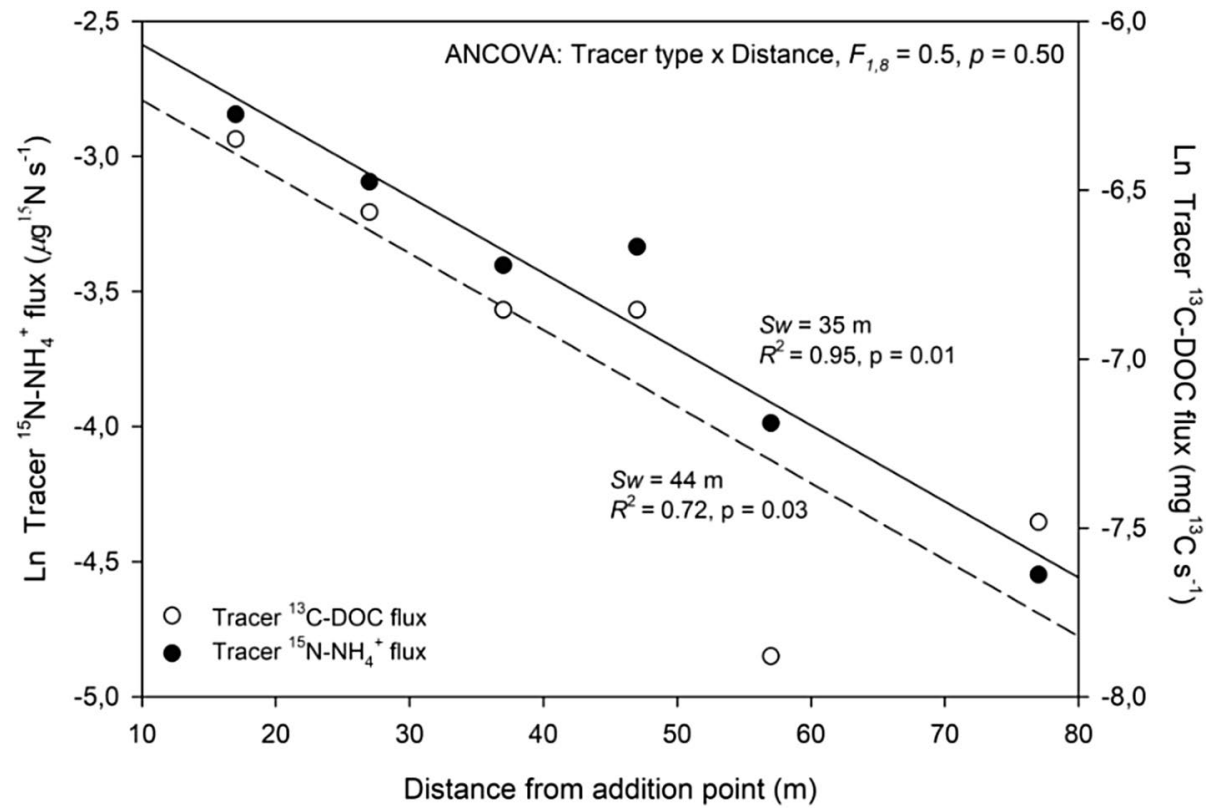

Table 1 Standing stocks of $\mathrm{C}$ ( $\mathrm{g} \mathrm{C} \mathrm{m}^{-2}$ reach) and $\mathrm{N}$ ( $\mathrm{g} \mathrm{N} \mathrm{m}^{-2}$ reach), $\mathrm{C}$ to $\mathrm{N}$ molar ratio, areal uptake of acetate $\left(U_{\text {acetate }}, \mathrm{mg} \mathrm{C} \mathrm{m}^{-2}\right.$ day $\left.^{-1}\right)$ and $\mathrm{NH}_{4}^{+}\left(U_{\mathrm{NH} 4}, \mathrm{mg} \mathrm{N} \mathrm{m}^{-2}\right.$ day $\left.{ }^{-1}\right)$, and the molar ratio of these uptakes $\left(U_{\text {acetate }}: U_{\mathrm{NH} 4}\right)$ for each compartment and for the entire reach based on data from plateau at 7 days

\begin{tabular}{|c|c|c|c|c|c|c|c|c|}
\hline Compartment & $\begin{array}{l}\text { C stock } \\
\mathrm{g} \mathrm{C} \mathrm{m}^{-2}\end{array}$ & $\begin{array}{l}\mathrm{N} \text { stock } \\
\mathrm{g} \mathrm{N} \mathrm{m}^{-2}\end{array}$ & $\begin{array}{l}\mathrm{C}: \mathrm{N} \\
\text { Molar ratio }\end{array}$ & $\begin{array}{l}U_{\text {acetate }} \\
\mathrm{mg} \mathrm{C} \mathrm{m}^{-2} \text { day }^{-1}\end{array}$ & $\begin{array}{l}U_{\text {acetate }}^{\mathrm{a}} \\
\text { day }^{-1}\end{array}$ & $\begin{array}{l}U_{\mathrm{NH} 4} \\
\mathrm{mg} \mathrm{N} \mathrm{m}^{-2} \text { day }^{-1}\end{array}$ & $\begin{array}{l}U_{\mathrm{NH} 4}^{\mathrm{a}} \\
\text { day }^{-1}\end{array}$ & $\begin{array}{l}U_{\text {acetate }}: U_{\mathrm{NH} 4} \\
\text { Molar ratio }\end{array}$ \\
\hline Epilithon & 2.9 & 0.10 & 33.2 & 107.4 & 0.040 & 0.30 & 0.0001 & 411.6 \\
\hline Bryophytes & 0.7 & 0.02 & 40.5 & 6.7 & 0.010 & 0.11 & 0.0001 & 71.9 \\
\hline FBOM & 10.3 & 0.24 & 50.7 & 152.6 & 0.015 & 0.18 & 0.0174 & 1000.3 \\
\hline Leaf litter & 34.4 & 0.89 & 45.0 & 255.7 & 0.007 & 0.72 & $<0.0001$ & 417.3 \\
\hline Small wood & 26.5 & 0.37 & 83.4 & 93.6 & 0.003 & 0.04 & $<0.0001$ & 2503.6 \\
\hline Reach total & 74.8 & 1.62 & & 616.0 & & 1.35 & & \\
\hline
\end{tabular}

FBOM fine benthic organic matter

${ }^{\mathrm{a}}$ Uptake normalized by the standing stocks

C. The C:N molar ratio varied among PUCs, ranging from 33.2 in epilithon to 83.4 in small wood (Table 1). The total assimilatory uptake determined from the sum of all compartment-specific uptakes was $1.35 \mathrm{mg} \mathrm{N} \mathrm{m}^{-2}$ day $^{-1}$ for $\mathrm{NH}_{4}{ }^{+}$and $616.0 \mathrm{mg} \mathrm{C} \mathrm{m}^{-2} \mathrm{day}^{-1}$ for acetate (Table 1). Leaf litter accounted for the largest proportion of this assimilatory uptake for the two elements $(53 \%$ for $\mathrm{N}$ and $42 \%$ for C), followed by epilithon for $\mathrm{N}$ uptake (22\%) and FBOM for C uptake (24\%). Small wood (3\%) and bryophytes (1\%) accounted for the lowest proportion of total assimilatory $\mathrm{N}$ and $\mathrm{C}$ uptake, respectively. The molar ratios between the compartment-specific $U_{\text {acetate }}$ and $U_{\mathrm{NH} 4}$ were $>1$, indicating a higher uptake for labile $\mathrm{C}$ than for $\mathrm{N}$ from the water column for all PUCs (Table 1). However, this ratio differed widely across PUCs, ranging from 71.9 in bryophytes to 2503.6 in small wood (Table 1).
At the end of the 7-day tracer addition, we accounted for $76 \%$ and $14 \%$ of the total ${ }^{15} \mathrm{~N}$ and ${ }^{13} \mathrm{C}$ added, respectively (Table 2). In this sense, PUCs contributed to the storage of $65 \%$ and $7 \%$ of the total ${ }^{15} \mathrm{~N}$ and ${ }^{13} \mathrm{C}$ added, respectively (Table 2). Leaf litter contributed to the largest fraction of this storage $\left(39.7 \%\right.$ of ${ }^{15} \mathrm{~N}$ added; $2.9 \%$ of ${ }^{13} \mathrm{C}$ added) and epilithon also contributed to a relevant fraction of it (14.7\% of ${ }^{15} \mathrm{~N}$ added; $2.3 \%$ of ${ }^{13} \mathrm{C}$ added).

Over the first 14 days after the addition ended, leaf litter showed a significant decline in the $\delta^{15} \mathrm{~N}$ and $\delta^{13} \mathrm{C}$ values. Based on this decline, the turnover rates of $\mathrm{N}$ and $\mathrm{C}$ for leaf litter were $0.088 \mathrm{day}^{-1}$ (i.e., a turnover time of 11.4 days) and 0.047 day $^{-1}$ (i.e., a turnover time of 21.3 days), respectively. Small wood also showed a significant decline in $\delta^{13} \mathrm{C}$ over time, with a turnover rate of $0.036 \mathrm{day}^{-1}$ (i.e., 
Table 2 Percentage of the total ${ }^{15} \mathrm{~N}$ and ${ }^{13} \mathrm{C}$ tracer stored in PUCs and macroinvertebrates or exported at the end of the addition

\begin{tabular}{lll}
\hline & Tracer & Tracer \\
& ${ }^{13} \mathrm{C}$ added & ${ }^{15} \mathrm{~N}$ added \\
& $\%$ & $\%$ \\
\hline Stored & & \\
Epilithon & 2.3 & 14.7 \\
Bryophytes & 0.2 & 1.9 \\
FBOM & 1.0 & 6.3 \\
Leaf litter & 2.9 & 39.7 \\
Small wood & 0.5 & 1.4 \\
Habroleptoides sp. & 0.113 & 0.56 \\
Oulimnius sp. & 0.001 & 0.01 \\
Radix sp. & 0.105 & 0.04 \\
Boyeria irene & 0.003 & 0.03 \\
Total stored & 7.2 & 64.8 \\
Exported & & \\
SPOM & 0.04 & 0.2 \\
NH $_{4}{ }^{+}$ & - & 8.6 \\
NO ${ }_{3}^{-}$ & - & 2.5 \\
DOC & 6.8 & - \\
Total exported & 6.8 & 11.2 \\
Reach total & 14.0 & 76.0 \\
\hline
\end{tabular}

FBOM fine benthic organic matter

a turnover time of 27.8 days). For the remaining PUCs, the declines in the $\delta^{15} \mathrm{~N}$ and $\delta^{13} \mathrm{C}$ values were not significant.

\section{Transfer of ${ }^{15} \mathrm{~N}$ and ${ }^{13} \mathrm{C}$ tracers to macroinvertebrates}

The biomass of the taxa of benthic macroinvertebrates considered in the tracer addition ( $81 \%$ of total abundance found in the reach) was $0.2 \mathrm{~g} \mathrm{DM} \mathrm{m}^{-2}$. This biomass was dominated by grazers (39\%; primarily Habroleptoides sp.) and predators (34\%; primarily Boyeria irene), followed by collector-filterers (15\%; primarily Hydropsyche sp.), collector-gatherers (11\%; primarily Radix sp.) and a negligible presence of shredders (1\%; primarily Nemoura sp.). Macroinvertebrate feeding groups considered in parameter calculations (grazers, collector-gatherers and predators) accounted for $84 \%$ of the total biomass of selected consumers. The total $\mathrm{N}$ and $\mathrm{C}$ standing stocks associated with the selected macroinvertebrates were $16.2 \mathrm{mg} \mathrm{N} \mathrm{m}^{-2}$ and $69.9 \mathrm{mg} \mathrm{C} \mathrm{m}^{-2}$ (Table 3 ), which represented $1 \%$ of the total $\mathrm{N}\left(1.64 \mathrm{~g} \mathrm{~N} \mathrm{~m}^{-2}\right)$ and $0.1 \%$ of the total $\mathrm{C}\left(74.9 \mathrm{~g} \mathrm{C} \mathrm{m}^{-2}\right)$ standing stock measured at the reach scale. The $\mathrm{N}$ and $\mathrm{C}$ standing stocks of the macroinvertebrates were dominated by Habroleptoides (37\% of $\mathrm{N}$ standing stock; $41 \%$ of $\mathrm{C}$ standing stock) and Boyeria irene (49\% of N standing stock; $44 \%$ of $\mathrm{C}$ standing stock). The $\mathrm{C}: \mathrm{N}$ molar ratios were similar
Table 3 Standing stocks of $\mathrm{C}\left(\mathrm{mg} \mathrm{C} \mathrm{m}^{-2}\right)$ and $\mathrm{N}\left(\mathrm{mg} \mathrm{N} \mathrm{m}^{-2}\right)$ and molar $\mathrm{C}$ to $\mathrm{N}$ ratio $(\mathrm{C}: \mathrm{N})$ for each sampled macroinvertebrate across the study reach

\begin{tabular}{lcll}
\hline Macroinvertebrate & $\begin{array}{l}\text { C stock } \\
\mathrm{mg} \mathrm{C} \mathrm{m}^{-2}\end{array}$ & $\begin{array}{l}\mathrm{N} \text { stock } \\
\mathrm{mg} \mathrm{N} \mathrm{m}^{-2}\end{array}$ & $\begin{array}{l}\mathrm{C}: \mathrm{N} \\
\text { Molar ratio }\end{array}$ \\
\hline Grazer-Habroleptoides sp. & 28.3 & 6.0 & 5.4 \\
Grazer-Oulimnius sp. & 2.5 & 0.5 & 5.5 \\
Collector gatherer-Radix sp. & 8.2 & 1.8 & 5.3 \\
Predator-Boyeria irene & 30.9 & 7.9 & 4.6 \\
Total & 69.9 & 16.2 & \\
\hline
\end{tabular}

among macroinvertebrates, with values close to 5 for all of them (Table 3).

All sampled macroinvertebrates were labelled with ${ }^{15} \mathrm{~N}$ and ${ }^{13} \mathrm{C}$ by the end of the 7-day tracer addition. Habroleptoides showed the highest isotopic tracer labelling, with $\delta^{15} \mathrm{~N}$ and $\delta^{13} \mathrm{C}$ tracer values following those of epilithon, its potential food source, along the reach. In fact, the $\delta^{15} \mathrm{~N}$ ratio between Habroleptoides and epilithon averaged $1.1 \pm 0.2$ along the reach (mean \pm SE; Fig. 2, a1). In contrast, the $\delta^{13} \mathrm{C}$ ratio between Habroleptoides and epilithon averaged $17.0 \pm 8.0$ (mean \pm SE; Fig. 2, a2). Oulimnius, another grazer that presumably feeds on epilithon, was less isotopically enriched than epilithon and showed a relatively constant isotopic signature along the reach for the two tracers (Fig. 2, b1 and b2). In relation to the collector-gatherer Radix, the $\delta^{15} \mathrm{~N}$ values closely followed those of the $\delta^{15} \mathrm{~N}$ in FBOM along the reach, and the isotopic ratio between them was $1.1 \pm 0.2$ (mean \pm SE; Fig. 2, c1). In contrast, the $\delta^{13} \mathrm{C}$ ratio between Radix and FBOM averaged $4.3 \pm 2.2$ (mean \pm SE; Fig. 2, c2). The predator Boyeria irene was less isotopically enriched than any of the other macroinvertebrate taxa sampled. The ratios between the average isotopic signal from all sampled primary consumers and the isotopic signal for this predator were $0.2 \pm 0.05$ for $\delta^{15} \mathrm{~N}$ and $0.1 \pm 0.04$ for $\delta^{13} \mathrm{C}$. At the end of the 7-day tracer addition, storage of $\mathrm{N}$ and $\mathrm{C}$ in sampled macroinvertebrates accounted for $0.6 \%$ and $0.2 \%$ of the total ${ }^{15} \mathrm{~N}$ and ${ }^{13} \mathrm{C}$ tracer added, respectively (Table 2 ).

\section{Discussion}

\section{Whole-reach $\mathrm{N}$ and $\mathrm{C}$ uptake}

Our results indicated that $\mathrm{NH}_{4}{ }^{+}$and acetate uptake in the study reach were high (i.e., short $S_{w}$ and high $V_{f}$ for both elements) as was anticipated in our initial prediction. Stream water $\mathrm{NH}_{4}{ }^{+}$was efficiently removed from the water column, exhibiting a $V_{f}$ of $3.0 \mathrm{~mm} \mathrm{~min}^{-1}$, that is within the range of values found in other headwater streams $\left(\mathrm{NH}_{4}{ }^{+} V_{f}\right.$ range: 0.2-10.6 mm $\mathrm{min}^{-1}$, Hall et al. 2002; von Schiller et al. 

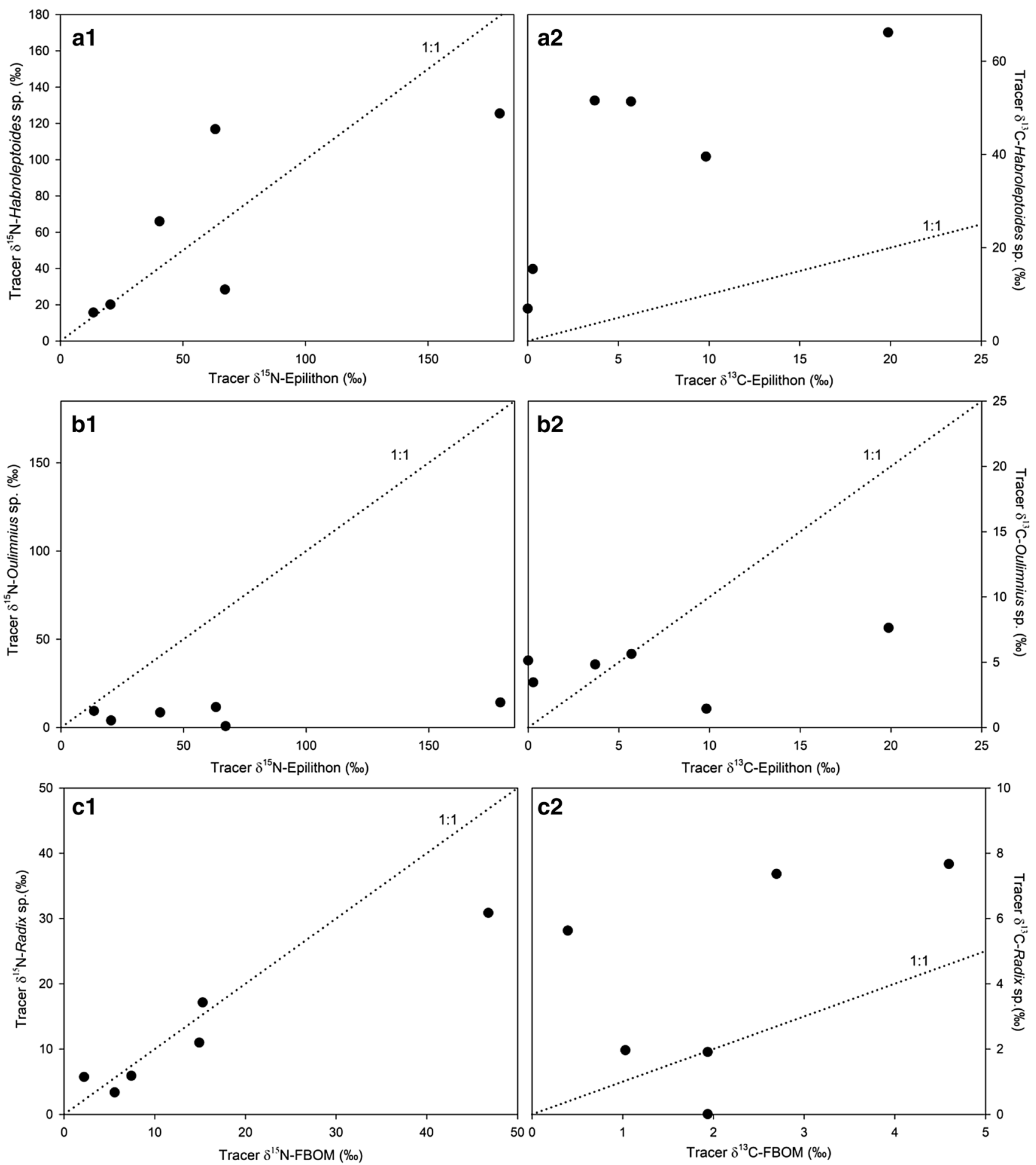

Fig. 2 Relationship between the isotopic signal of each macroinvertebrate taxon $(\mathbf{a}-\mathbf{c})$ and that of its potential food resource for the ${ }^{15} \mathrm{~N}$ tracer $(1)$ and the ${ }^{13} \mathrm{C}$ tracer (2). Values are from samples collected at plateau 7 days. The 1:1 relation is indicated on each panel with a pointed line

2008; Martí et al. 2009). Despite the fact that our study reach had a standing stock of leaf litter similar to that described by Tank et al. (2000), their reported values of $\mathrm{NH}_{4}{ }^{+} V_{f}$ were 10 times higher than our measured values. This may be explained by the fact that cold water temperatures limited microbial activity in our stream during the addition period (Fabre and Chauvet 1998; Brown et al. 2004). Indeed, measurements of ecosystem respiration in the study reach during 
the following autumn $\left(\mathrm{ER}=4.5 \mathrm{~g} \mathrm{O}_{2} \mathrm{~m}^{-2} \mathrm{day}^{-1}\right.$; Pastor et al. 2017) were 7 times lower than those found by Tank et al. (2000). Previous studies have indicated that $\mathrm{NH}_{4}{ }^{+} V_{f}$ is positively related to ecosystem respiration (Hall and Tank 2003) and negatively related to stream water temperature at low discharges (Butturini and Sabater 1998), which supports the observed interpretation.

The rapid $V_{f}$ estimated for acetate in our reach $\left(2.4 \mathrm{~mm} \mathrm{~min}^{-1}\right.$ ) was similar to those previously reported for in-stream uptake of labile DOC forms in streams $\left(V_{f}\right.$ range: 0.1-28.7 mm min ${ }^{-1}$, Kaplan et al. 2008; Martí et al. 2009; Johnson et al. 2009; Mineau et al. 2016). Despite the large amounts of detritus on the streambed in the sampling period, our results support that labile forms of DOC are at least as strongly retained as $\mathrm{NH}_{4}{ }^{+}$in streams (Wiegner et al. 2005; Martí et al. 2009; Johnson et al. 2009). Given the stream acetate concentration maintained during the addition, we assumed that only bacteria were able to take up the tracer ${ }^{13} \mathrm{C}$-acetate (Wright and Hobbie 1966; Newell 1984; Hall and Meyer 1998). We acknowledge that labile DOC, such as acetate, comprises a small fraction of the bulk DOC, but it represents the in-stream dynamics of a readily available form of C (Mineau et al. 2016). Moreover, our results support the idea that labile DOC can be an important energy source for heterotrophic bacteria developed on streambed substrata (Kaplan and Newbold 2003; Wiegner et al. 2015; Catalán et al. 2018; Seybold and McGlynn 2018).

\section{Relative contribution of PUCs to $\mathrm{N}$ and $\mathrm{C}$ uptake}

The microbial assemblages established on leaf litter showed the highest contribution to whole-reach uptake of $\mathrm{NH}_{4}{ }^{+}$and acetate in our stream. The importance of leaf litter to wholereach $\mathrm{NH}_{4}{ }^{+}$uptake was previously described in forested streams (Mulholland et al. 2000b; Tank et al. 2000). However, the few previous ${ }^{13} \mathrm{C}$-acetate addition studies (Hall and Meyer 1998; Simon et al. 2003; Collins et al. 2016) showed low or even non-detectable isotopic enrichment in leaf litter. Labelling by itself does not quantify the role of leaf litter in the uptake of DOC because the large amount of unlabelled detrital $\mathrm{C}$ in detritus diluted the ${ }^{13} \mathrm{C}$ tracer taken up by the active microbes (Hall and Meyer 1998; Collins et al. 2016). In contrast, our estimation of the specific compartment areal uptake at the whole-reach scale indicated that, despite a low ${ }^{13} \mathrm{C}$ enrichment, the relative contribution of heterotrophic bacteria developed on leaf litter was important to DOC uptake at whole-reach scale.

Our results showed differences in the relative contribution of different detrital compartments to whole-reach $\mathrm{NH}_{4}{ }^{+}$and acetate uptake. Small wood exhibited a moderate contribution to whole-reach acetate uptake despite its large standing stock, indicating a low use of water column DOC by the bacteria colonizing this substrate. This pattern does not necessarily indicate a reliance of microbial assemblages on the substrate $\mathrm{C}$, but most likely it suggests a low bacterial decomposer activity on small wood. Wood is considered poor-quality organic matter litter due to its high $\mathrm{C}: \mathrm{N}$ ratio and low surface-to-volume ratio (Allan and Castillo 2007; Arroita et al. 2012). These characteristics limit the development of microbial assemblages on wood, which results in low decomposition rates (Meentemeyer 1978; Melillo et al. 1982). FBOM was the second compartment after leaf litter contributing to whole-reach acetate uptake. Two similar previous ${ }^{13} \mathrm{C}$-acetate tracer additions reported $\mathrm{FBOM}$ as the most-labelled detrital compartment (Hall and Meyer 1998; Simon et al. 2003). FBOM is considered more refractory than leaf litter (Yoshimura et al. 2008), but in contrast to leaf litter, its microbial biomass is mainly formed by bacteria rather than by fungi (Weyers and Suberkropp 1996; Hamilton et al. 2001; Sanzone et al. 2001). Therefore, FBOM may contain a dominant bacterial biomass that would be more dependent on DOC than the bacteria colonizing the leaf litter. In this sense, if areal acetate uptake values obtained in our study are normalized by the compartment $\mathrm{C}$ standing stock, they are higher in FBOM $\left(0.015 \mathrm{day}^{-1}\right.$; Table 1$)$ than in leaf litter $\left(0.007 \mathrm{day}^{-1}\right.$; Table 1$)$. The higher relative contribution of leaf litter to whole-reach acetate uptake than that of FBOM was likely the result of the larger standing stock of leaf litter. Regarding $\mathrm{NH}_{4}{ }^{+}$uptake, leaf litter had 4 and 18 times greater areal $\mathrm{N}$ uptake than FBOM and small wood, respectively. As in previous ${ }^{15} \mathrm{~N}$ studies (Mulholland et al. 2000b; Tank et al. 2000), our results indicate that microbial assemblages in leaf litter were taking up more $\mathrm{N}$ than those assemblages in FBOM or small wood. This microbial biomass has large amounts of $\mathrm{C}$ available in leaf litter, but the leaf $\mathrm{N}$ content is low relative to the stoichiometric requirements for microbial growth. Our results indicate that to overcome the stoichiometric constraints caused by this large elemental imbalance, microbes rely upon dissolved $\mathrm{N}$ (Sterner and Elser 2002; Cheever et al. 2013; Pastor et al. 2014).

Epilithon contributed significantly to whole-reach areal $\mathrm{NH}_{4}{ }^{+}$and acetate uptake despite its low standing stock. In addition, epilithon had a similar $U_{\text {acetate }}: U_{\mathrm{NH} 4}$ molar ratio compared to leaf litter. These results suggest an important reliance on $\mathrm{N}$ by epilithon (auto- and heterotrophs), together with an important reliance on DOC by epilithic heterotrophic bacteria, thereby denoting a certain heterotrophic character of the epilithon. By contrast, as we expected, bryophytes showed a limited contribution to whole-reach $\mathrm{NH}_{4}{ }^{+}$uptake. Additionally, we observed $\mathrm{C}$ uptake in bryophytes, although at low rates, which is likely the result of the microbial biofilms commonly associated with them (Suren, 1988). The $U_{\text {acetate }}: U_{N H 4}$ ratio in bryophytes was low, reflecting their autotrophic character and its dependence on $\mathrm{N}$ from the water column. 
Differences found in this study in the rate of areal uptake versus uptake corrected for standing stocks for each PUC, highlight the potential consequences of changes in the standing stocks of different benthic compartments on $\mathrm{N}$ and $\mathrm{C}$ cycling at whole-ecosystem scale. Land use changes (e.g. reduction of riparian forest) or longer periods of dry conditions leading to forest water stress and increased leaf litter on the dry riverbed, may have important implications for in-stream $\mathrm{N}$ and $\mathrm{C}$ processing and downstream export.

\section{$\mathrm{N}$ and $\mathrm{C}$ transfer from PUCs to consumers}

Macroinvertebrate consumers were labelled with ${ }^{15} \mathrm{~N}$ and ${ }^{13} \mathrm{C}$ tracer at the end of the addition period, showing a transfer of $\mathrm{N}$ and DOC from the water column throughout PUCs to higher trophic levels. According to our results, each macroinvertebrate taxon seemed to assimilate the two elements from the same resource. Habroleptoides sp. reached the strongest labelling for both elements, reflecting the high enrichment in epilithon, its main food resource. Our results support findings from other studies showing the role of epilithon as a valuable pathway to transfer microbial N (Tank et al. 2000; Ashkenas et al. 2004; Norman et al. 2017) and bacterial C (Hall 1995; Hall and Meyer 1998; Simon et al. 2003; Parkyn et al. 2005; Collins et al. 2016) to higher trophic levels, even in forested streams where the epilithon biomass is low. In contrast, Oulimnius sp., another grazer that presumably feeds also on epilithon, showed a low enrichment, which was nearly constant among the samples and did not coincide with the pattern followed by the epilithon tracer. One possible explanation for this observation may be related to the morphology of Oulimnius sp., which is characterized by a thick, chitinous exoskeleton (Liess and Hillebrand, 2005) that results in a large body mass with slow turnover rates and long times to reach isotopic equilibrium. However, accordingly to the body mass correction proposed by Vander-Zanden et al. (2015), the isotopic incorporation rate for Oulimnius sp. was 3 days, which would be within the 7 days tracer addition performed in our experiment. Applying this correction for the other studied invertebrates, we obtained 3.4 days for Habroleptoides sp., 6.8 days for Radix sp. and 31 days for Boyeria irene. Therefore, only Boyeria irene showed an isotopic half-life higher than the experimental addition duration, which could explain the low enrichment found for this predator in our study. Unfortunately, we cannot reliably evaluate the transfer of $\mathrm{N}$ and $\mathrm{C}$ linked to the microbial assemblages established on leaf litter and small wood because the presence of shredders in our reach was extremely low during the study period. Scarcity of leaf-shredding invertebrates under flow intermittency has been previously described (Maamri et al. 1997; Muñoz 2003; Burgazzi et al. 2018). Moreover, travertine precipitation on leaf litter is common in calcareous streams, impeding invertebrate decomposer activity (Casas and Gessner 1999). The reduced abundance and biomass of this feeding group compared to other feeding groups in the studied stream suggests that the invertebrate-driven leaf processing is less relevant in this stream (Langhans and Tockner 2006; Datry et al. 2011) than other ways of detritus processing. For example, the relevance of the detrital pathway was apparent in the collector Radix sp., which obtained $\mathrm{N}$ and $\mathrm{C}$ from the microbes associated with the FBOM and retained a considerable proportion of ${ }^{15} \mathrm{~N}$ and ${ }^{13} \mathrm{C}$ tracer despite its low standing stock. Allochthonous $\mathrm{C}$ from detritus might allow consumers to survive when in-stream primary production is low, as during the autumn-winter period. The more recalcitrant but energetically high glucose from terrestrial inputs might be more consumed under nutritional stress for energy (Thorp and Bowes, 2017).

Habroleptoides sp. and Radix sp. were consistently more isotopically enriched than their potential food resources for both tracers, but especially for ${ }^{13} \mathrm{C}$. This label mismatch has been observed in previous ${ }^{15} \mathrm{~N}$ (Dodds et al. 2014) and ${ }^{13} \mathrm{C}$ tracer studies (Hall, 1995; Collins et al. 2016), and it was attributed to a selective assimilation by macroinvertebrates of a more biologically active fraction of their resource (e.g., algae, bacteria and fungi). Previous ${ }^{15} \mathrm{~N}$ (Mulholland et al. 2000a; Tank et al. 2000) and ${ }^{13} \mathrm{C}$ studies (Hall and Meyer 1998; Collins et al. 2016) showed that bulk detritus is less labelled than the associated microbial biomass. This dilution effect on the isotopic signature could be even more prominent in ${ }^{13} \mathrm{C}$ studies because the amount of detrital $\mathrm{C}$ is larger than that of detrital N. However, the wider mismatch for ${ }^{13} \mathrm{C}$ than for ${ }^{15} \mathrm{~N}$ label could also indicate a selective assimilation of bacterial C as was reported previously (Edwards and Meyer 1987, 1990; Hall and Meyer 1998; Collins et al. 2016).

\section{Storage of $\mathrm{N}$ and $\mathrm{C}$ in the study reach}

In our experiment, we accounted for $76 \%$ of the total ${ }^{15} \mathrm{~N}$ tracer added, with most ${ }^{15} \mathrm{~N}$ being stored in leaf litter and, to a lesser extent, in epilithon. This amount is within the range observed in other ${ }^{15} \mathrm{~N}$ tracer additions performed in forested streams (e.g., Mulholland et al. 2000b; Ashkenas et al. 2004). The remaining $24 \%$ of ${ }^{15} \mathrm{~N}$ was probably not detected because we may have underestimated the standing stocks. For example, a miscellaneous fraction of CBOM (>1 mm), not classifiable into leaf litter or wood, accounted for $27.7 \mathrm{~g} \mathrm{AFDM} \mathrm{m}^{-2}$ but was not used for standing stocks or for uptake calculations. Moreover, the macroinvertebrate biomass used for isotopic analyses accounted for $84 \%$ of the total macroinvertebrate biomass estimated in the studied reach; and therefore, another $16 \%$ of macroinvertebrate biomass was not considered in the mass balance. Apart from standing stocks, some ${ }^{15} \mathrm{~N}$ may 
have been lost due to abiotic sorption onto stream sediments (Richey et al. 1985; Peterson et al. 2001), involvement in processes that occur in hyporheic waters (Triska et al. 1989) or consumption by meiofauna, and therefore not included in our study.

Although we observed relatively high biological demand for DOC in our reach, we were able to account for only $14 \%$ of the total ${ }^{13} \mathrm{C}$ tracer added at the end of the addition. Approximately half of the total ${ }^{13} \mathrm{C}$ tracer that could be accounted for was stored in leaf litter and epilithon, whereas the other half was exported downstream as DOC or mineralized to $\mathrm{CO}_{2}$. The same explanations offered above for ${ }^{15} \mathrm{~N}$ tracer could at least partially explain the missing ${ }^{13} \mathrm{C}$ tracer, including abiotic absorption (McDowell 1985), hyporheic processes (Sobczak and Findlay 2002) and consumption by meiofauna (Suberkropp 1998). However, we must also consider that some $\mathrm{C}$ was lost by respiration. In this sense, Simon et al. (2003) calculated that, as in our study, only $0.8-6.3 \%$ of the ${ }^{13} \mathrm{C}$ tracer added was stored within the studied reaches, with a large amount of the ${ }^{13} \mathrm{C}$ missing due to respiration. These results could indicate that an important fraction of the labile DOC removed from the water column by bacteria was rapidly mineralized and lost as $\mathrm{CO}_{2}$ via respiration rather than being stored or incorporated into the food web (McDowell and Fisher 1976).

\section{Conclusions and perspectives}

We found that similar to $\mathrm{NH}_{4}{ }^{+}$, acetate, a labile form of DOC, is also rapidly taken up from the water column when large amounts of detritus are available. Among PUCs, microbial assemblages established on leaf litter showed the highest contribution to whole-reach $\mathrm{NH}_{4}{ }^{+}$and acetate uptake, indicating the influence of inputs of leaf litter on the immobilization of $\mathrm{N}$ and DOC in streams. The predominant role of leaf litter in the whole-reach uptake of $\mathrm{NH}_{4}{ }^{+}$ and acetate relative to other compartments was the result of the large standing stock of leaf litter. Changes in the PUC stocks may imply changes in $\mathrm{N}$ and $\mathrm{C}$ cycling at broader scales. Our results also demonstrated that N and DOC taken up by PUCs can be rapidly transferred to macroinvertebrate consumers thereby extending the retention time of these elements within the ecosystem. Future research should consider analysing only the actively cycling $\mathrm{N}$ and $\mathrm{C}$ fraction from food resources to reduce the observed label mismatch and improve the interpretation of the results (Dodds et al. 2014). Finally, the small percentage of the total added ${ }^{13} \mathrm{C}$ tracer retained in the study reach at the end of the addition suggested that labile forms of DOC such as acetate could be rapidly mineralized and lost as $\mathrm{CO}_{2}$ via respiration, indicating that future studies on $\mathrm{C}$ cycling should account also for this pathway.
Acknowledgements We are thankful to I. Sanpera-Calbet, N. De Castro-Català, M. Ribot, L. Proia, Ll. Gómez-Gener and JP. Casas-Ruiz for field assistance. This study was funded by the Spanish Ministry of Economics and Competitiveness through SPACESTREAM (CGL201788640-C2-2-R) and MED-FORESTREAM (CGL2011-30590-C02-02) projects. E. Bastias was granted by a FPI PhD fellowship from the Spanish Ministry of Science and Innovation. D. von Schiller received additional financial support from the Basque Government (Consolidated Research Group: Stream Ecology 7-CA-18/10).

\section{References}

Allan JD, Castillo MM (2007) Stream ecology: structure and function of running waters, 2nd edn. Springer, Dordrecht

American Public Health Association (1995) Standard methods for the examination of water and wastewater, 19th edn. American Public Health Association, New York

Arroita M, Aristi I, Flores L, Larrañaga A, Díez J, Mora J, Romaní AM, Elosegi A (2012) The use of wooden sticks to assess stream ecosystem functioning: comparison with leaf breakdown rates. Sci Total Environ 440:115-122. https://doi.org/10.1016/j.scito tenv.2012.07.090

Ashkenas L, Johnson S, Gregory S, Tank JL, Wollheim M (2004) A stable isotope tracer study of nitrogen uptake and transformation in an old-growth forest stream. Ecology 85:1725-1739. https:// doi.org/10.1890/03-0032

Baldy V, Gobert V, Guerold F, Chauvet E, Lambrigot D, Charcosset JY (2007) Leaf litter breakdown budgets in streams of various trophic status: effects of dissolved inorganic nutrients on microorganisms and invertebrates. Freshw Biol 52:1322-1335. https://doi.org/10 $.1111 / \mathrm{j} .1365-2427.2007 .01768 . x$

Bernhardt ES, Likens GE (2002) Dissolved organic carbon enrichment alters nitrogen dynamics in a forest stream. Ecology 83:16891700. https://doi.org/10.2307/3071988

Bernhardt ES, McDowell WH (2008) Twenty years apart: comparisons of DOM uptake during leaf leachate releases to Hubbard Brook Valley streams in 1979 versus 2000. J Geophys Res 113:G03032. https://doi.org/10.1029/2007JG000618

Bott TL, Kaplan LA, Kuserk FT (1984) Benthic bacterial biomass supported by streamwater dissolved organic matter. Microb Ecol 10:335-344. https://doi.org/10.1007/BF02015558

Brown JH, Gilloly JF, Allen AP, Savage VM, West GB (2004) Toward a metabolic theory of ecology. Ecology 85:1771-1789. https:// doi.org/10.1890/03-9000

Burgazzi G, Guareschi S, Laini A (2018) The role of small-scale spatial location on macroinvertebrate community in an intermittent stream. Limnetica 37:319-340. https://doi.org/10.23818/ limn.37.26

Burgherr P, Meyer EI (1997) Regression analysis of linear body dimensions vs. dry mass in stream macroinvertebrates. Arch Hydrobiol 139:101-112

Butturini A, Sabater F (1998) Ammonium and phosphate retention in a Mediterranean stream: hydrological versus temperature control. Can J Fish Aquat Sci 55:1938-1945. https://doi.org/10.1139/ f98-071

Casas JJ, Gessner MO (1999) Leaf litter breakdown in a Mediterranean stream characterised by travertine precipitation. Freshw Biol 41:781-793

Catalán N, Casas-Ruiz JP, Arce MI, Abril M, Bravo AG, del Campo R, Gómez-Gener L (2018) Behind the scenes: mechanisms regulating climatic patterns of dissolved organic carbon uptake in headwater streams. Glob Biogeochem Cycles 32(10):1528-1541. https://doi. org/10.1029/2018gb005919 
Cheever B, Webster J, Bilger E, Thomas S (2013) The relative importance of exogenous and substrate-derived nitrogen for microbial growth during leaf decomposition. Ecology 94:1614-1625. https://doi.org/10.1890/12-1339.1

Collins SM, Sparks JP, Thomas SA, Wheatley SA, Flecker AS (2016) Increased light availability reduces the importance of bacterial carbon in headwater stream food webs. Ecosystems 19:396-410. https://doi.org/10.1007/s10021-015-9940-3

Datry T, Corti R, Claret C, Philippe M (2011) Flow intermittence controls leaf litter breakdown in a French temporary alluvial river: the "drying memory". Aquat Sci 73:471-483

Dodds WK, Evans-White MA, Gerlanc NM, Gray L, Gudder DA, Kemp MJ, López AL, Wollheim WM (2000) Quantification of the nitrogen cycle in a prairie stream. Ecosystems 3:574-589. https://doi.org/10.1007/s100210000050

Dodds WK, Martí E, Tank JL, Pontius J, Hamilton SK, Grimm NB, Bowden WB, Gregory S (2004) Carbon and nitrogen stoichiometry and nitrogen cycling rates in streams. Oecologia 140:458467. https://doi.org/10.1007/s00442-004-1599-y

Dodds WK, Collins SM, Hamilton SK, Tank JL, Johnson S, Webster JR, Martí E (2014) You are not always what we think you eat: selective assimilation across multiple whole-stream isotopic tracer studies. Ecology 95:2757-2767. https://doi. org/10.1890/13-2276.1

Edwards RT, Meyer JL (1987) Bacteria as a food source for black fly larvae in a blackwater river. J N Am Benthol Soc 6:241-250. https://doi.org/10.2307/1467311

Edwards RT, Meyer JL (1990) Bacterivory by deposit-feeding may fly larvae (Stenonema spp.). Freshw Biol 24:453-462. https:// doi.org/10.1111/j.1365-2427.1990.tb00724.x

Fabre E, Chauvet E (1998) Leaf breakdown along an altitudinal stream gradient. Arch Hydrobiol 141:167-179

Gessner MO, Chauvet E, Dobson M (1999) A perspective on leaf litter breakdown in streams. Oikos 85:377-384. https://doi. org/10.2307/3546505

Ghosh S, Leff LG (2013) Impacts of labile organic carbon concentration on organic and inorganic nitrogen utilization by a stream biofilm bacterial community. Appl Environ Microbiol 79:7130 7141. https://doi.org/10.1128/AEM.01694-13

Glibert PM, Middelburg JJ, McClelland JW, Jake Vander Zanden M (2018) Stable isotope tracers: enriching our perspectives and questions on sources, fates, rates, and pathways of major elements in aquatic systems. Limnol Oceanogr. https://doi. org/10.1002/lno. 11087

Goodale CL, Thomas SA, Fredriksen G, Elliott EM, Flinn KM, Butler TJ, Walter MT (2009) Unusual seasonal patterns and inferred processes of nitrogen retention in forested headwaters of the Upper Susquehanna River. Biogeochemistry 93:197-218. https ://doi.org/10.1007/s10533-009-9298-8

Gordon ND, McMahon TA, Finlayson BL (1992) Stream hydrology. An introduction for ecologists, 2nd edn. Wiley, Chichester

Hall RO (1995) Use of stable carbon isotop addition to trace bacterial carbon through a stream food web. J N Am Benthol Soc 14:269-277. https://doi.org/10.2307/1467779

Hall RO, Meyer JL (1998) The trophic significance of bacteria in a detritus-based stream food web. Ecology 79:1995-2012. https ://doi.org/10.2307/176704

Hall RO, Tank JL (2003) Ecosystem metabolism controls nitrogen uptake in streams in Grand Teton National Park, Wyoming. Limnol Oceanogr 48:1120-1128. https://doi.org/10.4319/ 1o.2003.48.3.1120

Hall RO, Peterson BJ, Meyer JL (1998) Testing a nitrogen-cycling model of a forest stream by using a ${ }^{15} \mathrm{~N}$ tracer addition. Ecosystems 1:283-298. https://doi.org/10.1007/s100219900022
Hall RO, Bernhardt ES, Likens GE (2002) Relating nutrient uptake with transient storage in forested mountain streams. Limnol Oceanogr 47:255-265. https://doi.org/10.4319/lo.2002.47.1.0255

Hamilton SK, Tank JL, Raikow DF, Wollheim WM, Peterson BJ, Webster JR (2001) Nitrogen uptake and transformation in a midwestern U.S. stream: a stable isotope enrichment study. Biogeochemistry 54:297-340. https://doi.org/10.1023/A:10106 35524108

Holmes RM, McClelland JW, Sigman DM, Fry B, Peterson BJ (1998) Measuring ${ }^{15} \mathrm{~N}^{-\mathrm{NH}_{4}}{ }^{+}$in marine, estuarine and fresh waters: an adaptation of the ammonia diffusion method for samples with low ammonium concentrations. Mar Chem 60:235-243. https:// doi.org/10.1016/S0304-4203(97)00099-6

Johnson LT, Tank JL, Arango CP (2009) The effect of land use on dissolved organic carbon and nitrogen uptake in streams. Freshw Biol 54:2335-2350. https://doi.org/10.1111/j.1365-2427.2009.02261.x

Kaplan LA, Newbold JD (2003) The role of monomers in stream ecosystem metabolism. In: Findlay SEG, Sinsabaugh RL (eds) Aquatic ecosystems: interactivity of dissolved organic matter. Academic Press, San Diego, pp 97-119

Kaplan LA, Wiegner TN, Newbold JD, Ostrom PH, Gandhi H (2008) Untangling the complex issue of dissolved organic carbon uptake: a stable isotope approach. Freshw Biol 53:855-864. https://doi. org/10.1111/j.1365-2427.2009.02261.x

Langhans SD, Tockner K (2006) The role of timing, duration, and frequency of inundation in controlling leaf litter decomposition in a river-floodplain ecosystem (Tagliamento, northeastern Italy). Oecologia 147:501-509

Liess A, Hillebrand H (2005) Stoichiometric variation in C: N, C: P, and $\mathrm{N}$ : $\mathrm{P}$ ratios of litoral benthic invertebrates. J N Am Benthol Soc 24:256-269. https://doi.org/10.1899/04-015.1

Lowe WH, Likens GE (2005) Moving headwater streams to the head of the class. Bioscience 55:196-197. https://doi.org/10.1641/00063568(2005)055\%5b0196:MHSTTH\%5d2.0.CO;2

Maamri A, Chergui H, Pattee E (1997) Leaf litter processing in a temporary northeastern Moroccan river. Arch Hydrobiol 140:513-553

Martí E, Fonollà P, von Schiller D, Sabater F, Argerich A, Ribot M, Riera JL (2009) Variation in stream C, N and P uptake along an altitudinal gradient: a space-for-time analogue to assess potential impacts of climate change. Hydrol Res 40:123-127. https://doi. org/10.2166/nh.2009.090

McDowell WH (1985) Kinetics and mechanisms of dissolved organic carbon retention in a headwater stream. Biogeochemistry 1:329 352. https://doi.org/10.1007/BF02187376

McDowell WH, Fisher SG (1976) Autumnal processing of dissolved organic matter. Ecology 57:561-569. https://doi. org/10.2307/1936440

Meentemeyer V (1978) Macroclimate and lignin control of litter decomposition rates. Ecology 59:465-472. https://doi. org/10.2307/1936576

Melillo J, Aber JD, Muratore JF (1982) Nitrogen and lignin control of hardwood leaf litter decomposition dynamics. Ecology 63:621626. https://doi.org/10.2307/1936780

Meyer E (1989) The relationship between body length parameters and dry mass in running water invertebrates. Arch Hydrobiol 117:191-203

Meyer JL (1994) The microbial loop in flowing waters. Microb Ecol 28:195-199. https://doi.org/10.1007/BF00166808

Mineau MM, Wollheim WM, Buffam I, Findlay SEG, Hall RO Jr, Hotchkiss ER, Koenig LE, McDowell WH, Parr TB (2016) Dissolved organic carbon uptake in streams: a review and assessment of reach-scale measurements. J Geophys Res Biogeosci 121:2019-2029. https://doi.org/10.1002/2015JG003204

Mulholland PJ (2004) The importance of in-stream uptake for regulating stream concentrations and outputs of $\mathrm{N}$ and $\mathrm{P}$ from a forested watershed: evidence from long-term chemistry records 
for Walker Branch watershed. Biogeochemistry 70:403-426. https://doi.org/10.1007/s10533-004-0364-y

Mulholland PJ, Newbold JD, Elwood WJ, Leigh AF, Webster JR (1985) Phosporous spiralling in a woodland stream: seasonal variations. Ecology 66:1012-1023. https://doi. org/10.2307/1940562

Mulholland PJ, Tank JL, Sanzone DM, Wollheim WM, Peterson BJ, Webster JR, Meyer JL (2000a) Food resources of stream macroinvertebrates determined by natural abundance stable $\mathrm{C}$ and $\mathrm{N}$ isotopes and a ${ }^{15} \mathrm{~N}$ tracer addition. J N Am Benthol Soc 19:146-157. https://doi.org/10.2307/1468287

Mulholland PJ, Tank JL, Sanzone DM, Wollheim WM, Peterson BJ, Webster JR, Meyer JL (2000b) Nitrogen cycling in a forest stream determined by a ${ }^{15} \mathrm{~N}$ tracer addition. Ecol Monogr 70:471-493. https://doi.org/10.2307/2657212

Mulholland PJ, Valett HM, Webster JR, Thomas SA, Cooper LW, Hamilton SK, Peterson BJ (2004) Stream denitrification and total nitrate uptake rates measured using a field ${ }^{15} \mathrm{~N}$ tracer addition approach. Limnol Oceanogr 49:809-820. https://doi.org/10.4319/ 10.2004.49.3.0809

Muñoz I (2003) Macroinvertebrate community structure in an intermittent and a permanent Mediterranean streams (NE Spain). Limnetica 22:107-116

Newbold JD, Elwood JW, O’Neill RV, Sheldon AL (1983) Phosphorous dynamics in a woodland stream ecosystem: a study of nutrient spiralling. Ecology 64:1249-1265. https://doi.org/10.2307/1937833

Newell SY (1984) Bacterial and fungal productivity in the marine environment: a contrastive overview. Colloq Int Centre Natl Rech Sci (Marseill) 331:133-139

Norman BC, Whiles MR, Collins SM, Flecker AS, Hamilton SK, Johnson SL, Crowl T (2017) Drivers of nitrogen transfer in stream food webs across continents. Ecology 98(12):3044-3055. https://doi. org/10.1002/ecy.2009

Parkyn SM, Quinn JM, Cox TJ, Broekhuizen N (2005) Pathways of N and $\mathrm{C}$ uptake and transfer in stream food webs: an isotope enrichment experiment. J N Am Benthol Soc 24:955-975. https://doi. org/10.1899/04-082.1

Pastor A, Compson ZG, Dijkstra P, Riera JL, Martí E, Sabater F, Hungate BA, Marks JC (2014) Stream carbon and nitrogen supplements during leaf litter decomposition: contrasting patterns for two foundation species. Oecologia 176:1111-1121. https://doi. org/10.1007/s00442-014-3063-y

Pastor A, Lupon A, Gómez-Gener Ll, Rodríguez-Castillo T, Abril M, Arce MI, Catalán N (2017) Local and regional drivers of headwater stream metabolism: insights from the first AIL collaborative project. Limnetica 36(1):67-86

Peipoch M, Gacia E, Blesa A, Ribot M, Riera JL, Martí E (2014) Contrasts among macrophyte riparian species in their use of stream water nitrate and ammonium: insights from ${ }^{15} \mathrm{~N}$ natural abundance. Aquat Sci 76:203-215. https://doi.org/10.1007/s0002 7-013-0330-7

Peterson BJ, Wollheim WM, Mulholland PJ, Webster JR, Meyer JL, Tank JL, Morrall DD (2001) Control of nitrogen export from watersheds by headwater streams. Science 292:86-90. https:// doi.org/10.1126/science. 1056874

Pozo J, González E, Díez JR (1997) Inputs of particulate organic matter to streams with different riparian vegetation. J N Am Benthol Soc 16:602-611

Richey JS, McDowell WH, Likens GE (1985) Nitrogen transformation in a small mountain stream. Hydrobiologia 124:129-139. https:// doi.org/10.1007/BF00006795

Sanzone DM, Tank JL, Meyer JL, Mulholland PJ, Findlay SEG (2001) Microbial incorporation of nitrogen in stream detritus. Hydrobiologia 464:27-35. https://doi.org/10.1023/A:1013930102876

Seybold E, McGlynn B (2018) Hydrologic and biogeochemical drivers of dissolved organic carbon and nitrate uptake in a headwater stream network. Biogeochemistry 138:23-48. https://doi. org/10.1007/s10533-018-0426-1

Sigman DM, Altabet MA, Michener R, Mccorkle DC, Fry B, Holmes RM (1997) Natural abundance-level measurement of the nitrogen isotopic composition of oceanic nitrate: an adaptation of the ammonia diffusion method. Mar Chem 57:227-242. https://doi. org/10.1016/S0304-4203(97)00009-1

Simon KS, Benfield EF, Macko SA (2003) Food web structure and the role of epilithic biofilms in cave streams. Ecology 84:2395-2406. https://doi.org/10.1890/02-334

Sobczak WV, Findlay S (2002) Variation in bioavailability of dissolved organic carbon among stream hyporheic flow path. Ecology 83:3194-3209. https://doi.org/10.1890/00129658(2002)083\%5b3194:VIBODO\%5d2.0.CO;2

Sterner RW, Elser JJ (2002) Ecological stoichiometry: the biology of elements from molecules to biosphere. Princeton University Press, Princeton

Suberkropp K (1998) Microorganisms and organic matter processing. In: Naiman RJ, Bilby RE (eds) River ecology and management. Springer, New York, pp 120-143

Suren AM (1988) The ecological role of bryophytes in high alpine streams of New Zealand. Verh. Internat. Verein Theor. Angew. Limnol 23:1412-1416

Tachet H, Richoux P, Bournaud M, Usseglio-Polatera P (2000) Invertébrés d'eau douce. Systématique, biologie, écologie. CNRS éditions, Paris

Tank JL, Meyer JL, Sanzone DM, Mulholland PJ, Webster JR, Peterson BJ, Wollheim WM, Leonard LN (2000) Analysis of nitrogen cycling in a forest stream during autumn using a ${ }^{15} \mathrm{~N}$-tracer addition. Limnol Oceanogr 45:1013-1029. https://doi.org/10.4319/ lo.2000.45.5.1013

Tank JL, Rosi-Marshall EJ, Baker MA, Hall RO (2008) Are rivers just big streams? A pulse method to quantify nitrogen demand in a large river. Ecology 89:2935-2945. https://doi. org/10.1890/07-1315.1

Tank JL, Martí E, Riis T, von Schiller D, Reisinger A, Dodds W, Whiles M, Ashkenas L, Bowden W, Collins S, Crenshaw C, Crowl T, Griffiths N, Grimm N, Hamilton S, Johnson S, McDowell W, Norman B, Rosi-Marshall E, Simon K, Thomas S, Webster J (2018) Partitioning assimilatory nitrogen uptake in streams: an analysis of stable isotope tracer additions across continents. Ecol Monogr 88(1):120-138. https://doi.org/10.1002/ecm.1280

Thorp JH, Bowes RE (2017) Carbon sources in riverine food webs: new evidence from amino acid isotope techniques. Ecosystems 20:1029. https://doi.org/10.1007/s10021-016-0091-y

Trimmer M, Grey J, Heppell CM, Hildrew AG, Lansdown K, Stahl H, Yvon-Durocher G (2012) River bed carbon and nitrogen cycling: state of play and some new directions. Sci Total Environ 434:143158. https://doi.org/10.1016/j.scitotenv.2011.10.074

Triska FJ, Kennedy VC, Avanzino RJ, Zellweger GW, Bencala KE (1989) Retention and transport of nutrients in a third order stream in northwest California: hyporheic processes. Ecology 70:18931905. https://doi.org/10.2307/1938120

Vander-Zanden MJ, Clayton MK, Moody EK, Solomon CT, Weidel BC (2015) Stable isotope turnover and half-life in animal tissues: a literature synthesis. PLoS One 10(1):e0116182. https://doi. org/10.1371/journal.pone.0116182

Vannote LR, Minshall GW, Cummins KW, Sedell JR, Cushing CE (1980) The River Continuum Cocept. Can J Fish Aquat Sci 37:130-137. https://doi.org/10.1139/f80-017

von Schiller D, Martí E, Riera JL, Sabater F (2007) Effects of nutrients and light on periphyton biomass and nitrogen uptake in Mediterranean streams with contrasting land uses. Freshw Biol 52:891-906. https://doi.org/10.1111/j.1365-2427.2007.01742.x

von Schiller D, Martí E, Riera JL, Ribot M, Marks JC, Sabater F (2008) Influence of land use on stream ecosystem function in a 
Mediterranean catchment. Freshw Biol 53:2600-2612. https://doi. org/10.1111/j.1365-2427.2008.02059.x

Wallace JB, Eggert SL, Meyer JL, Webster JR (1997) Multiple trophic levels of a forest stream linked to terrestrail litter inputs. Science 227:102-104. https://doi.org/10.1126/science.277.5322.102

Webster JR, Tank JL, Wallace JB, Meyer JL, Eggert SL, Ehrman TP, McTammany ME (2000) Effects of litter exclusion and wood removal on phosphorus and nitrogen retention in a forest stream. Verh. Internat. Verein Limnol. 27:1337-1340

Weyers HS, Suberkropp K (1996) Fungal and bacterial production during the breakdown of yellow poplar leaves in 2 streams. J N Am Benthol Soc 15:408-420. https://doi.org/10.2307/1467795

Wiegner TN, Kaplan LA, Newbold JD (2005) Contribution of dissolved organic $\mathrm{C}$ to stream metabolism: a mesocosm study using 13C-enriched tree-tissue leachate. J N Am Benthol Soc 24:48-67. https://doi.org/10.1899/0887-3593(2005)024\%3c0048:CODOC $\mathrm{T} \% 3 \mathrm{e} 2.0 . \mathrm{CO} ; 2$

Wiegner TN, Kaplan LA, Ziegler S, Findlay R (2015) Consumption of terrestrial dissolved organic carbon by stream microorganisms.
Aquat Microb Ecol 75:225-237. https://doi.org/10.3354/ame01 761

Wilcox HS, Wallace JB, Meyer JL, Benstead JP (2005) Effects of labile carbon addition on a headwater stream food web. Limnol Oceanogr 50:1300-1312. https://doi.org/10.4319/lo.2005.50.4.1300

Wright RT, Hobbie JE (1966) Use of glucose and acetate by bacteria and algae in aquatic ecosystems. Ecology 47:447-464. https://doi. org/10.2307/1932984

Yoshimura C, Gessner MO, Tockner K, Furumai H (2008) Chemical properties, microbial respiration, and decomposition of coarse and fine particulate organic matter. J N Am Benthol Soc 27:664-673. https://doi.org/10.1899/07-106.1

Publisher's Note Springer Nature remains neutral with regard to jurisdictional claims in published maps and institutional affiliations. 